\title{
KRAMÁŘSKÉ PÍSNĚ V RAJHRADSKÉ BENEDIKTINSKÉ KNIHOVNĚ*
}

\author{
Jindra Pavelková (Brno)
}

\author{
Broadside Ballads in the Library of the Benedictine Monastery in Rajhrad
}

\begin{abstract}
The Rajhrad collections currently contain 81 song prints that can be classified as broadside ballads. Most of them are stored in boxes, like many other small prints from the monastic library that came there in the 19th century. Only a few provenance notes make it possible to identify the original owners of at least some of the prints. The analysis has also shown that almost half of the ballads were printed in Brno workshops; these represent song production from Prague, Hradec, Králové, Jindřichův Hradec, Litomyšl, Jihlava, Znojmo, Vienna, the New Town of Vienna, Linz, Krems and Skalice. Other places of publication than Brno are represented only by individuals. For almost a quarter of the prints, the place and date of publication cannot be precisely determined. It is only known that they were printed sometime in the 18th century. The vast majority of songs are religious - only seven prints are devoted to a secular theme. The clearly predominant language of the printed production is German, because the only surviving bound collection of chapbooks (in Czech špaliček) consists exclusively of German songs. From the 1780s, Czech predominated in the press. The only rock print in the set is in Slovak.
\end{abstract}

Keywords: broadside ballads - library of the Benedictine monastery in Rajhrad - Brno prints - 18th century - 19th century

\section{Úvod}

Na následujících řádcích bude představen fond kramářských písní uložených dnes v klášterní knihovně rajhradských benediktinů. Je nutné již na začátku př́spěvku předeslat, že kramářských písní se v Rajhradě nenachází žádné významné množství, naopak, ve srovnání s dalšími skupinami drobných tisků, jakými byla kázání, oslavné řeči či modlitby, jde spíše o sbírku menšího rozsahu. Přesto ale má smysl se i této skupině titulů věnovat, nebot' se jedná o součást celého fondu a poznání této problematiky přispívá k získání ucelených znalostí o celé knihovně.

Vzhledem k tomu, že kramářské písně obecně mají v téměř $60 \% \%^{1}-80 \%{ }^{2}$ ráz duchovní písně, je obtížné stanovit přesnou hranici mezi tituly, které ještě do skupiny kramářských písní přiřadit, a které již považovat za liturgické písně. V tomto ohledu nám bohužel nepomůže dochování tisků, protože je v rajhradské knihovně uložen pouze jeden špalíček, jinak jsou tisky samostatně uloženými entitami. ${ }^{3}$ Vzhledem k tomu, že obsah krabiček, ve kterých je v Rajhradě tento typ produkce nejčastěji uložen, je velmi různorodý a vznikal, jak je uvedeno níže, různými způsoby, bylo potřeba si nejprve vymezit, které tisky ještě budou mezi kramářské písně zahrnuty, a které již nikoliv. Stranou zájmu tak zůstávají ty položky, které nenaplňují definici kramářských tisků svým rozsahem (mají více než osm listů), nebo tisky přinášejících př́mo mešní zpěvy typu Pange lingua. ${ }^{4}$

Pro stanovení materie obsažené v příspěvku vychází autorka $\mathrm{z}$ definice kramářské písně navržené Jakubem Ivánkem $\mathrm{v}$ roce $2017^{5}$ a používané i pro vymezení badatelského zájmu kolektivu projektu NAKI II Kramářské písně v brněnských historických fondech. ${ }^{6}$ Kramářská píseň je tak definována svou publikační formou; jedná se o drobné několikastránkové sešitky tištěné levným způsobem na levném papíru. Tisky mohou obsahovat jednu či více písniček a někdy jsou doprovázeny jednoduchou obrazovou složkou, která ale nemusí s obsahem písně/písní souviset. ${ }^{7}$ Stranou zájmu příspěvku tak zůstávají další tisky, které bychom mohli označit jako tisky kramářské, obsahující např. modlitby, svaté obrázky apod.

Příspěvek se nejprve zaměří na fyzické dochování kramářských písní a způsob jejich uložení v rajhradském fondu, dále budou popsány konkrétní kramářské písně uchovávané dnes v rajhradské benediktinské knihovně. Samostatná pozornost bude věnována též kramářským písním vydaným

\footnotetext{
* Příspěvek vznikl v rámci Institucionální podpory na dlouhodobý koncepční rozvoj výzkumné organizace - Moravská zemská knihovna v Brně. ' Kramářské písně. In Encyklopedieknihy.cz [online]. Knihovna AV ČR, v. v. i. [Cit. 1. 5. 2021]. Dostupné z: https://www.encyklopedieknihy.cz/ 2 IVÁNEK 2017, s. 205

3 Ve čtyřech př́ipadech se jedná o př́ivazky v konvolutu a v jednom př́ípadě o špalíček (s 29 písničkami), zbylé tisky jsou dochovány jako samostatné entity v krabičkách.

${ }^{4}$ Konkrétně České Pange lingua je v krabičkách spolu s kramářskými písněmi dochováno třikrát ve dvou různých výtiscích z první poloviny 19. století. Knihovna Benediktinského opatství Rajhrad (dále KBOR), sig. R-III.a.3044,9, R-III.a.4087,5, R-III.a.4089,15.

IVÁNEK 2017, s. 224-225.

${ }^{6}$ Kód projektu DG18P02OVV021, poskytovatel Ministerstvo kultury, doba řešení 2016-2022.

GLOMBOVÁ 2020, s. 10.
} 
v Brně a v jejich rámci analýze těch evidovaných v rajhradské knihovně. Na závěr bude prripojen bibliografický soupis všech dosud identifikovaných kramářských písní.

\section{Dochování a uložení kramářských tisků v rajhradské benediktinské knihovně}

Při zpracování rajhradské benediktinské knihovny se dosud podařilo identifikovat 81 titulů, které můžeme přiřadit ke kramářským písním. Pět titulů je v knihovně dochováno ve dvou exempláŕích, jeden titul nalezneme ve fondu dokonce třikrát. Vyhledávání tohoto typu literatury v rajhradském fondu ztěžuje fakt, že klášter této produkci nevěnoval žádnou zvláštní pozornost, tisky se do fondu dostávaly nejspíše z pozůstalostí jednotlivých řeholníků (či jejich prríbuzných). Tomu odpovídá i způsob uložení - kramářské písně se dochovaly bud' vevázané v konvolutu spolu s dalšími formátově podobnými tisky, nebo uložené v dřevěné či lepenkové krabičce. Abecední lístkový katalog rajhradské knihovny však nemá samostatné lístky pro př́ivazky či jednotlivé tisky uložené v krabičkách, informace o těchto dílech se v něm dají nalézt pouze na lístku hlavního díla (v případě konvolutu) či prvního díla (v prrípadě krabiček). U písní dochovaných v konvolutech tak může dojít $\mathrm{k}$ nálezu dalších položek při postupné moderní katalogizaci knihovny.

\section{Konvoluty}

Pro literaturu, která byla součástí knihovny již v 18 . století, máme doložen způsob uložení v konvolutech. Takto je dochována většina drobných př́ležitostných tisků zejména brněnské produkce. Konvoluty mají tendenci uchovávat dohromady tisky, které spolu nějakým způsobem souvisí, minimálně se dá tušit, že vznikly zájmem jedné osoby. ${ }^{8}$

Tento způsob uložení drobných tisků je vedle rajhradské knihovny typický také např. pro knihovnu brněnských augustiniánů. V obou prrípadech však bohatství obsažené v konvolutech uniká informacím v lístkovém knihovním katalogu, kde jsou svazky označeny pouze podle prvního díla, či dokonce jménem svého sestavovatele. Pro rajhradskou knihovnu mají největší zásluhu o dochování tohoto typu drobné, převážně brněnské produkce zejména tamější řhoholníci Pavel Harlacher a Maurus Haberhauer. ${ }^{9}$ V rajhradské knihovně je tak dnes dochováno několik konvolutů, které obsahují zejména modlitby, kázání či oslavné řeči. ${ }^{10} \mathrm{Je}$ s podivem, že součástí těchto konvolutů není také písňová produkce, např̀. i kramářské písně.

V konvolutu dochované kramářské písně nejsou součástí objemných souborů, ke kterým se řadí svazky uvedené výše, jež shromažd'ují několik desítek drobných tisků z produkce brněnských, olomouckých, pražských a rakouských tiskáren, mnohdy v několika exemplárích roztroušených po různých svazcích. Bohužel dané konvoluty nedávají tušit, zda vznikly péčí některého z rajhradských řeholníků, byly takto již do knihovny získány, nebo k sobě jednotlivé tituly byly prriřazeny na základě formátu a obsahových souvislostí a $v$ rámci péče o knihovní fond jim byla pořízena společná vazba.

Zcela konkrétně: píseň ke sv. Antonínu Paduánskému se nalézá ve svazku spolu s dílem Hieronyma Veita Regule, Aneb Spůsob Žiwota, Bratrůw a Sester, třetjho Ržádu Swatého Otce Frantisska,... z roku $1750 .{ }^{11}$ Zde je patrná obsahová souvislost daná př́slušností Antonína z Padovy k františkánskému řádu. Kniha vyvázaná $v$ usňové vazbě nese pouze razítko rajhradské klášterní knihovny používané k označování př́růstků v 19. století. Dá se tedy usuzovat, že oba tituly se do knihovny dostaly již svázané, a konvolut tak vznikl péčí původního majitele, patrně se vztahem $\mathrm{k}$ františkánům.

Stejně tak se již do rajhradské knihovny jako komplet dostala patrně i píseň ke sv. Janu Nepomuckému, která je zařazena do svazku spolu se spisem Maxmiliana Siegela VIA CRUCIS, LUCIS, \& DUCIS,... z roku 1733, dílem Alfonse Maria de Liguori Besuchungen des allerheiligsten Sacraments, ... z roku 1772, tiskem 18. století Tag-Zeiten, Von der glorwürdigen und gnadenreichen Jungfrauen Maria von Trost a DEVOTIO QUINQUE-DIALIS ... INTERCESSIONE D. JOANNIS NEPOMUCENI, ... z roku $1721 .{ }^{12}$ Zdánlivě nesouvisející tisky mohl k duchovním cvičením a modlitbám používat i některý z rajhradských řeholníků. Svazek však nemá žádnou provenienci a je svázán do obvyklé pergamenové vazby používané $\mathrm{v}$ rajhradském klášteře $\mathrm{v}$ druhé polovině 18. století, a není tedy možné vyloučit ani to, že mu uspořádání dal až některý z rajhradských knihovníků.

Ve svazku stejné vazební úpravy pak nacházíme dvě kramářské písně, které jsou spolu s dalšími šesti tisky (mimo jiné zpěvy ke mši svaté, litaniemi ke svatým a Písní k nejsvětější oběti novozákonní) přivázány k tisku Der nach dem Sinne der katholischen Kirche singende Christ vydanému ve Fuldě v roce $1781 .{ }^{13}$

\section{Krabičky}

Větší množství písní je dochováno v krabičkách různých formátů, ${ }^{14}$ které sloužily k uložení drobných a př́ležitostných tisků s náboženskou tematikou (modlitby, kázání, přistoupení k bratrstvům, mešní pořádky), oslavných řečí, jednacích řádů, drobných teologických spisů či teologických spisů vycházejících v sešitech, divadelních her, výročních zpráv, katalogů výstav, cestovních průvodců či torzálně dochovaných tisků. Uspořádání tisků v krabičkách je nahodilé, jen

\footnotetext{
${ }^{8}$ Zde stojí za zmínku dva konvoluty rukopisů a tisků uložených v rajhradské rukopisné KBOR, sig. R 33 a R 34 (více k tomu viz PAVELKOVÁ 2018, s. 81-98).

${ }^{9}$ DOKOUPIL 1978, s. 6.

${ }^{10}$ Zde zejména KBOR, sig. R-C.I.c.52, R-C.II.dd.13, R-E.I.c.19, R-E.II.gg.10, R-E.II.gg.11, R-E.II.gg.13, R-E.II.gg.16, R-E.II.gg.21, R-E.II.gg.23, R-P.f.26, R-R.I.ccc.29, R-R.II.bbb.13, R-Y.I.e.5, R-Z.II.a.18, R-Z.f.18.

${ }^{11}$ KBOR, sig. R-H.I.f.26.

${ }^{12}$ Tamtéž, sig. R-Z.II.d.40

${ }^{13}$ Tamtéž, sig. R-Z.e.50.

${ }^{14}$ Zmiňovaných krabiček se v knihovně nachází omezené množství (133 kusů), protože je autorka článku prošla všechny, v této oblasti by tedy k dalším nálezům již dojít nemělo. Krabičky jsou signaturně vřazeny do systému první depozitní místnosti a uloženy jsou ve spodních policích regálů II.b., III.a., III.b., IV.a., IV.b., V.a., V.b., VI.a., VI.b., VII.a. a VIII.a.
} 


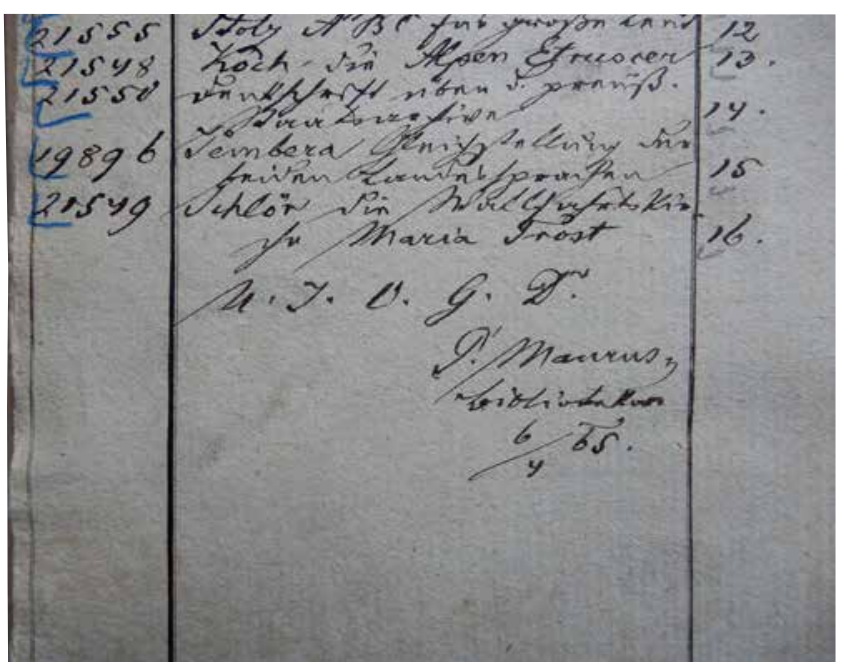

Obr. 1. Detail z přehledu obsahu krabičky s podpisem knihovníka Maura Kintra s datem, kdy tisky inventarizoval (KBOR, sig. $\mathrm{R}-$ III.a.4079).

v několika málo př́ípadech vzbuzuje dojem nějakého záměru (obsahové, jazykové hledisko). Tisky jsou v krabičkách uloženy napříč formáty, i když nejčastěji se setkáváme s $8^{\circ}$ a $4^{\circ}$, výjimkou ale není ani foliový formát či větši různě složené jednolisty. Menší formáty se nacházejí povětšinou i ve větších krabičkách poskládané na sobě ve dvou sloupcích.

Bohužel nemáme žádné přesné informace $\mathrm{k}$ tomu, kdy rajhradská knihovna ke způsobu ukládání drobných tisků do krabiček prisstoupila. $Z$ dnes dochovaných 133 krabiček je jich 25 dřevěných potažených mramorovým papírem $\mathrm{s}$ papírovými štítky s nápisem Miscellanea a signaturou na hřbetě. Zbylé krabičky jsou lepenkové potažené na deskách modrým mramorovým a na hřbetě černým papírem a modrým štítkem se zlaceným nápisem MISCELLANEA. Starší krabičky mají zavírání důmyslně zajištěné dřevěným špalíčkem, který zapadá těsně k zadní desce krabičky, mladší jsou na tkanice, dnes značně potrhané a nefunkční. V pravém rohu přední desky mají novější krabičky trojúhelníkový štítek s uvedením počtu obsažených svazků. Na přídeští povětšinou dva papírové pásky jistí list s obsahem krabičky.

Ani tyto seznamy nám však neumožňují učinit závěry o době vzniku krabiček, vznikly totiž patrně při reinventarizaci krabiček v roce 1865 péčí tehdejšího knihovníka Maura Kintra. Kinter většinu z nich zakončil svým podpisem a datem inventarizace, $v$ několika př́padech se pod tímto záznamem nalézají dopisky o dalších do krabičky přičleněných položkách.

To svědčí o tom, že krabičky byly doplňovány. Pro průběžné doplňování hovoří i sám fakt, že většina z krabiček obsahuje více položek, než kolik jich bylo v dané krabičce původně uloženo, což je zréejmé zejména z prostého faktu, že se všechny tisky do krabiček nevejdou. S ohledem na úvodní seznam (obsah) krabiček jsou jednotlivé tisky průběžně číslovány, číslování však ne vždy, spíše výjimečně, odpovídá skutečnému uložení v krabičce, které vychází ze snahy tisky do krabičky umístit, což v číselném pořadí mnohdy nelze. ${ }^{15}$

Seznam tisků obsažených v krabičce také někdy obsahuje odkaz na prrírůstkové číslo z knihovního repertáře či informaci o původní signatuře, obojí je ale uvedeno i na samotných tiscích. V seznamu je někdy dopsána charakteristika tisků - např. Kázání.

Jen minimální množství tisků uložených v krabičkách obsahuje provenienční zápisky. Pouze $\mathrm{v}$ pěti krabičkách, které obsahují i kramářské či duchovní písně, je uložen nějaký tisk s rukopisným záznamem. Nejhojněji se setkáváme se jménem Víta Jana Nepomuka Konrada, otce posledního rajhradského probošta Otmara Konrada (proboštem 1764-1812), což je ovšem dáno tím, že uložené tisky se týkají bratrstev, jejichž byl V. J. N. Konrad členem. Zápisy mají podobu předtištěné formulace doplněné o jméno a datum vstupujícího. ${ }^{16} \mathrm{~V}$ jednom prípadě zde nalezneme i jméno samotného pozdějšího rajhradského probošta O. Konrada.${ }^{17}$ Krabičky tedy patrně vznikly z materiálů, které se do knihovny dostaly po Konradově smrti. V takovém př́padě by $\mathrm{O}$. Konrad přispěl do fondu klášterní knihovny 13 kramářskými písněmi. ${ }^{18}$

Jedna z krabiček, ve které se nacházejí i kramářské písně, zřejmě shromažd'uje tisky, které patřily Bedovi Dudíkovi (1815-1890). Jeho jméno ještě bez jména řádového je uvedeno na tisku Kirchengesänge für die Studierenden zu Kremsier z roku $1836 .{ }^{19}$ Podle obsahu celé krabičky, která shromažd'uje 44 tisků z církevních zpěvů, modliteb, ale zejména historie a teologie a prríruček pro studující, se dá usuzovat, že se jedná o tisky, které B. Dudík shromáždil z větší části již $\mathrm{v}$ době před vstupem do benediktinského řádu či na začátku svých studií v Olomouci. Pokud vyjdeme z tohoto předpokladu, tak B. Dudík přispěl do fondu kramářských písní dvěma exemplári brněnského tisku Gesang Eines sich dem Willen Gottes ergebenden Christens z roku 1780. ${ }^{20}$

Poslední provenienční príípisky se nacházejí v obsáhlé krabičce s drobnými tisky o odpustcích, modlitbami, divadelními hrami, rituálem, pojednáním o hmyzu či dvěma spisky Olivera Legiponta. V této krabičce je také uložen jediný v rajhradské knihovně dochovaný špalíček. Každá z dochovaných proveniencí však patř́ jinému z rajhradských řeholníků, a je tedy spíše pravděpodobné, že krabička byla uspořádána $\mathrm{z}$ různých $\mathrm{v}$ klášteře dochovaných materiálů. Zde dochované kramářské písně ${ }^{21}$ tedy patrně nemůžeme připsat

\footnotetext{
${ }^{15}$ Různé formáty vyžadují různou orientaci tisku, menší formáty jsou většinou ve dvou sloupcích na větších formátech.

${ }^{16}$ KBOR, sig. R-III.a.3038,4 - Johannes Konrad 30. April 1743; R-III.a.3038,9 - 1722, 16. Julij, Joannes Vitus Konrad; sig. R-III.a.3044,22 - Vitus Nepomucenus Conrad Den 27 Jän. Im Jahre 1724; sig. R-III.a.3044,23 - Ist geschrieben worden Joannes Vitus Conrad Den 3. Monaths Maji Im 1731 Jahr.

${ }^{17}$ KBOR, sig. R-III.a.3038,6 - Carolus Conrad, 28. September von 5 biß 6 Uhr Abend, S. Ignatii Eingeschrieben in Znaimb 1745.

${ }^{18}$ Vzhledem k tomu, že mezi těmito písněmi jsou čtyři brněnské tisky a jeden tisk znojemský věnované Janu Nepomuckému, zdá se pravděpodobné, že jejich původním majitelem byl proboštův otec Vít Jan Nepomuk Konrad.

${ }^{19}$ KBOR, sig. R-III.a.4069,4 - Dudik Franz.

${ }^{20}$ Tamtéž, sig. R-III.a.4069,6a a 6 b.

${ }^{21}$ Vedle uvedeného špalíčku s 29 písničkami jsou zde samostatně uloženy ještě dvě písničky.
} 
do majetku ani rajhradského profesa Emiliana Wagnera, kterému patřil tisk Welice Pohodlný Spůsob nábožné, a vctiwě se klaněti Neyswětěgssý Swátosti Oltářnj,... vytištěný v Brně v roce 1774, ${ }^{22}$ ani rajhradskému knihovníkovi a posléze opatovi Viktoru Šlosarovi (opatem 1832-1854), který označil tisk Handbuchlein der immerwährenden Anbetung des hochwürdigen Sakraments des Altars, ... vydaný v roce 1774 v Mikulově ještě svým světským jménem Martin. ${ }^{23}$

Z výše uvedeného je tedy zřejmé, že krabičky mohou obsahovat tisky, které patřily jednomu majiteli - rajhradskému řeholníkovi, případně členům jeho rodiny - stejně tak ale mohou obsahovat nahodile seskupené tituly, které se v jednu dobu sešly v knihovně (at' již z pozůstalostí řeholníků, či jiným způsobem, napřr. akvizicí knihovníka) a bylo potřeba je uložit.

\section{Špalíček ${ }^{24}$}

Jak již bylo výše uvedeno, v rajhradské knihovně je dochován pouze jediný špalíček. Nachází se v něm 29 jazykově německých písniček převážně s mariánskou tematikou, zastoupeny jsou ale i písně ke sv. Anně či Janovi Nepomuckému. V rámci písní mariánských se pak jedná převážně o tisk pro poutníky do Mariazell, jedenkrát je zastoupena i poutní bazilika Maria Taferl a rovněž Wagram.

Špalíček, ve kterém jsou jednotlivé tisky pouze svázány nití, vykazuje značné známky opotřebení. Proto větší část tisků nejsme schopni přiřadit do žádné tiskárny. Dochovaly se značně torzovitě, mnohdy ze tří písniček zůstala zachována jen část druhé písně a píseň třetí. Lépe dochované tisky jsou produkcí zejména brněnské svobodovské tiskárny a dále tiskáren ve Znojmě, Jindřichově Hradci, Kremži, Linci a Vídeňském Novém Městě a vydány byly v průběhu 18. století.

Špalíček nenese žádnou provenienci, podle které bychom mohli určit, kdy a jak se do rajhradské klášterní knihovny dostal.

\section{Kramářské písně dochované v rajhradské benediktinské knihovně}

Veškeré v Rajhradě dochované tisky, které můžeme počítat ke kramářským písním, mají osmerkový formát a převážná většina $\mathrm{z}$ nich byla vytištěna $\mathrm{v}$ Brně, proto se i brněnské produkci kramářských písní budeme $\mathrm{v}$ závěru tohoto textu věnovat podrobněji.

Bylo to nejspíše dáno přímými kontakty rajhradského kláštera s brněnskými tiskárnami, zejména s tiskárnou rodiny Svobodovy, že se s kramářskými písněmi v klášterní knihovně setkáváme $v$ takovém počtu (brněnských tisků je podchyceno 39 , z toho pět je ve dvou a jeden ve třech exemplářích). Ostatně i u dalších drobných tisků je blízkost Brna

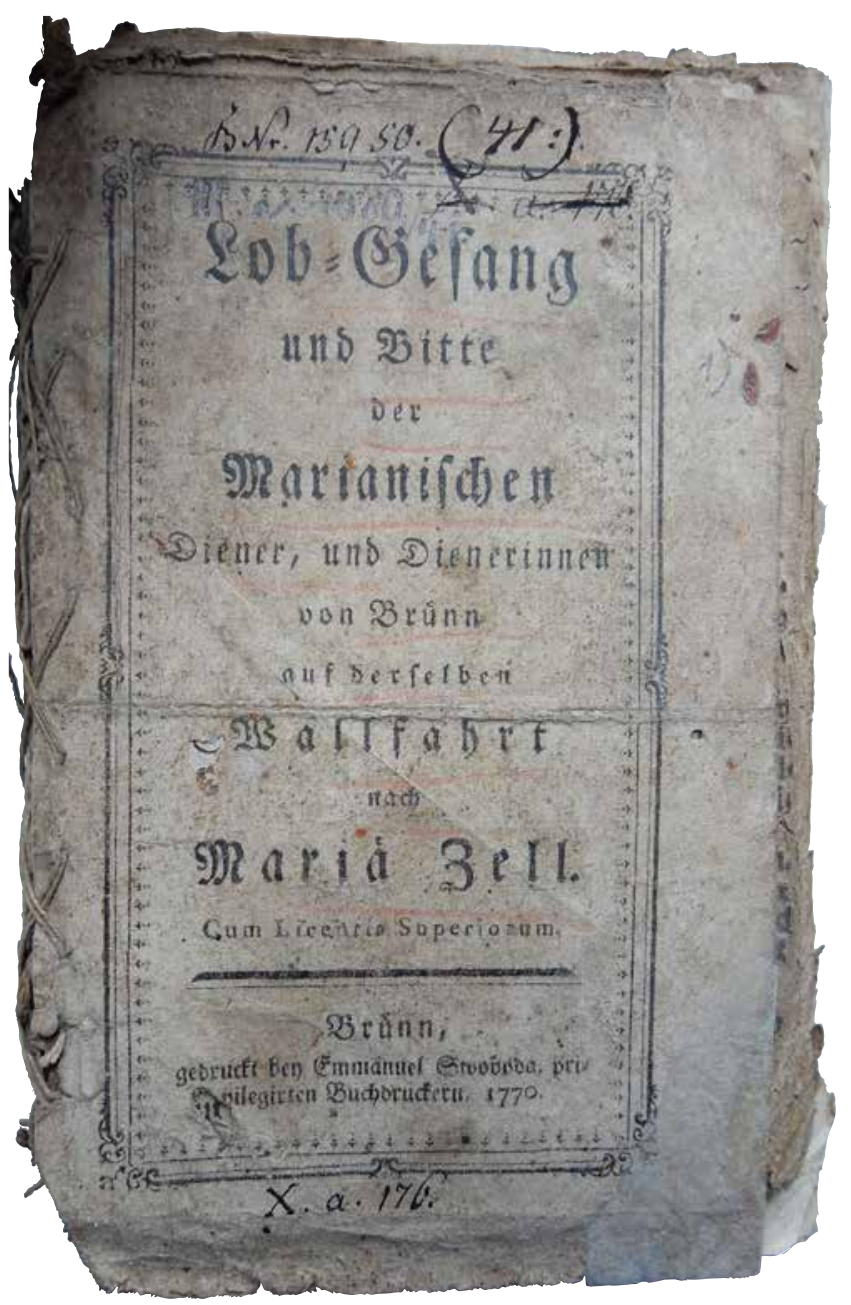

Obr. 2. Titulní tisk špalíčku 29 německých písniček (KBOR, sig. R-III.a.4080,41).

patrná - tyto tisky byly v Rajhradě $\mathrm{k}$ dispozici ve vícero exemplárích. Bohužel nedisponujeme $\mathrm{v}$ této oblasti archivním materiálem, který by nám vztah rajhradského kláštera a brněnských tiskáren 18. a 19. století (před vznikem vlastní Papežské knihtiskárny benediktinů rajhradských ${ }^{25}$ ) osvětlil. Představu o něm si můžeme utvořit pouze na základě v Rajhradě dochované brněnské produkce a tisků, které benediktinský klášter sám inicioval či prŕímo objednal.

Mezi rajhradskými kramářskými písněmi z brněnské produkce jsou zastoupeny v 18. století svobodovská tiskárna, tiskárna Jana Silvestra Siedlera a Leopolda Františka Hallera. V 19. století se pak setkáváme s produkcí rohrerovské tiskárny z období, kdy ji vedla vdova po Rudolfu Rohrerovi Hedvika (1839-1852), tiskárny Jana Gastla a Karla Winikera.

Z dalších míst vydání evidujeme mezi kramářskými písněmi Prahu (7 titulů), ${ }^{26}$ Znojmo (5 titulů), ${ }^{27}$ Hradec Králové

\footnotetext{
${ }^{22}$ KBOR, sig. R-III.a.4080,35 - P. Aemilian Wagner Bened. 1. Cžervna po poledni.

${ }^{23}$ KBOR, sig. R-III.a.4080,31 - Schllosar Martin, 11. November 6 bis 10 Uhr. — Scriptum hoc die ... 1814 ante inductionem meam.

${ }^{24}$ KBOR, s. R-III.a.4080,41.

${ }^{25}$ K tématu rajhradské tiskárny více viz HEILANDOVÁ 2013, s. 60-90.

${ }^{26}$ Dílny Tomáše Tábora, Jana H. Pospíšila, arcibiskupské tiskárny.

${ }^{27}$ Dílny Jana Václava Svobody a Jana Antonína Preisse.
} 
(2 tituly), ${ }^{28}$ Jihlavu, Jindřichův Hradec a Litomyšl (po 1 titulu $)^{29}$ a ze zahraničních center Skalici (1 titul), Vídeň (3 tituly), ${ }^{30}$ Kremži (2 tituly), ${ }^{31}$ Linec, Vídeňské Nové Město (po 1 titulu). ${ }^{32}$ U 19 položek nelze místo vydání přesněji určit, dá se usuzovat na českou či moravskou provenienci. ${ }^{33}$

U datace tisků vycházíme tam, kde je to možné povětšinou z let, kdy fungovala tiskárna, která je vytiskla. Tam, kde se nepodařilo tisky jednotlivým tiskárnám přiřadit, můžeme obecně konstatovat, že se jedná až na výjimky ${ }^{34}$ o tisky 18. století, bližší chronologické zařazení však neumožňují.

Nejstarší kramářskou písní je tisk Christliche Reimblein Und Auffmunterung de $\beta$ Sünders zur zeitlichen Bu $\beta$ vytištěný patrně v Brně po roce $1705,{ }^{35}$ který se do knihovny dostal z majetku rajhradského probošta Otmara Konrada. Další tisky spadají do 30. a 40. let 18. století $\left(1736,{ }^{36} 1743^{37}\right.$ a $\left.1746^{38}\right)$. V první polovině 18. století byly u Johanna Jacoba Koplitze v Kremži vydány Drey schöne neue Geistliche Lieder,... ${ }^{39}$ obsahující tři písně ke sv. Anně, dva tisky duchovních písní $\mathrm{z}$ dílny Jana Václava Svobody ve Znojmě ${ }^{40}$ či Fünf schöne Neüe Andächtige Lieder zu dem Heiligen Johannes von Nepomuck ${ }^{41}$ vytištěné u Jana Bedřicha Jakeše v Jindřichově Hradci. Hojně zastoupena jsou zejména 50 . léta 18 . století, a to brněnskými mariánskými tisky MARIA Jn Jhrer Gnaden-Zell ... z let $1753,{ }^{42} 1755^{43}$ a $1758^{44}$ a čtyřmi tisky věnovanými Janu Nepomuckému (třemi tištěnými v Brně ${ }^{45}$ a jedním ze Znojma ${ }^{46}$ ), které opět pocházely z majetku probošta Konrada.
Do obou polovin 18. století svým působením zasahovaly tiskárny Ignaze Antona Präxla v Kremži (1732-1766), Antonína Jana Preise ve Znojmě (1743-1787), Samulea Müllera ve Vídeňském Novém Městě (1717-1757) a Johanna Auingera v Linci (1733-1774). Pouze letopočty fungování těchto tiskáren je tak možno datovat tisky Drey schöne gantz neue Kirchfahrt-Lieder,..., ${ }^{47}$ Drey schöne neue Geistliche Lieder..., Anmütiges Gesang zu dem Heil. Johann von Nepomuck, ${ }^{48}$ Drey schöne neue Zeller-Lieder ${ }^{49}$ a Geistliches Lied, Denen armen Seelen in dem Fegfeuer zu Trost, nach verrichtem Heil. Creutz-Weeg zu singen. ${ }^{50}$ stejně tak do tohoto období spadá produkce tiskárny uváděné v impresu jako Jacob Maxim Swobodischen Erben. ${ }^{51}$

Do 60 . let 18 . století spadají dvě v rajhradské knihovně dochované kramářské písně vytištěné v Brně u Emanuela Svobody, ${ }^{52}$ stejné označení tiskárny v impresu mají i dvě dochované kramářské písně z let 1770 a $1776 .^{53}$ Do 70 . let 18. století jsou dále datovány tisky Ein Osterlied, ${ }^{54}$ Pjseň o Božských Ctnostech ${ }^{55}$ a do následujícího desetiletí pak tisky Gesang Eines sich dem Willen Gottes ergebenden Christens $^{56}$ a Lobgesang ... heiligen Vaters Ignazius von Lojola..., ${ }^{57}$ Pjseň při Požehnánj s neyswětěgssj Swátosti Oltár̆nj ${ }^{58}$ opět z produkce brněnské tiskárny. Tři tisky byly v 80. letech 18. století vydané opět v Brně, dva z nich se prímo vážou $\mathrm{k}$ jedné $\mathrm{z}$ farností spravovaných rajhradským klášterem, a to k Domašovu. ${ }^{59}$ Další tisk s domašovskou tematikou je datován lety $1784-1798 .^{60}$ Do stejné doby pak

\footnotetext{
${ }^{28}$ Dílna Jana H. Pospíšila.

${ }^{29}$ V Jihlavě dílna Fabiána Beinhauera, v Jindřichově Hradci dílna Jana Bedřicha Jakeše a v Litomyšli dílna Václava Vojtěcha Turečka.

${ }^{30}$ Dílny Jana Tomáše Trattnera a nakladatelství Wiener Zeitung.

${ }^{31}$ Dílny Johanna Jacoba Kopitze a Ignaze Antona Präxla.

${ }^{32}$ V Linci dílna Johanna Auingera a ve Vídeňském Novém Městě Samuela Müllera.

${ }^{33}$ Zejména u jednotlivých blíže neurčených tisků svázaných do špalíčku sig. R-III.a.4080,41 by se dalo usuzovat na znojemský původ alespoň části tisků. Brněnské tiskárny jsou na základě typografie vyloučeny.

${ }^{34}$ Pouze dva tisky je možno datovat do první čtvrtiny (KBOR, sig. R-IIII.a.4090,19), respektive poloviny 19. století (KBOR, sig. R-III.a.4062,44).

${ }^{35}$ Tamtéž, sig. R-III.a.3044,18.

36 Tamtéž, sig. R-III.a.4080,41, přív. 11.

37 Tamtéž, sig. R-III.a.4080,41, přív. 18-20.

${ }^{38}$ Tamtéž, sig. R-III.a. 4080,41, př́iv. 22.

${ }^{39}$ Tamtéž, sig. R-III.a. 4080,41, přív. 6.

${ }^{40}$ Tamtéž, sig. R-III.a. 4080,41, přív. 3 a R-III.a. 4080,41, přív. 7.

${ }^{41}$ Tamtéž, sig. R-III.a. 4080,41, přív. 8.

42 Tamtéž, sig. R-III.a. 4080,41, př́iv. 23.

${ }^{43}$ Tamtéž, sig. R-III.a. 4080,41, přív. 27.

44 Tamtéž, sig. R-III.a. 4080,41, přív. 28.

45 Tamtéž, sig. R-III.a. 3044,8a, R-III.a. 3044,8b a R-III.a. 3044,8d.

46 Tamtéž, sig. R-III.a. 3044,8e.

${ }^{47}$ Krems: Ignaz Anton Präxl. KBOR, sig. R-III.a.4080,41, př́iv. 26.

${ }^{48}$ Znojmo: Antonín Jan Preiss. KBOR, sig. R-III.a.4080,41, přív. 25 a R-Z.II.d.40, přív. 3.

${ }^{49}$ Vídeňské Nové Město: Samuel Müller. KBOR, sig. R-III.a.4080,41, přív. 15.

${ }^{50}$ Linz: Johann Auinger. KBOR, sig. R-III.a.4080,41, přív. 24.

${ }^{51}$ Tedy dědici Jakuba Maxmiliána Svobody. Pod tímto označením vydávala brněnská svobodovská tiskárna své tisky v letech 1743 až 1752 . Zde KBOR, sig. R-III.a.4080,41, př́iv. 21.

${ }^{52}$ Tisky jsou datovány lety 1767 (KBOR, sig. R-III.a.3044.8c) a 1768 (KBOR, sig. R-III.a.3043a,25b). První tisk pochází z majetku probošta Konrada.

${ }^{53} 1770$ (KBOR, sig. R-III.a.4080,41), 1776 (KBOR, sig. R-III.a.3043a,24).

${ }_{54} 1778$ (KBOR, sig. R-III.a.3038,1). Tisk je z majetku Otmara Konrada.

${ }_{55} 1778$ (KBOR, sig. R-III.a.4080,17 a R-III.a.3044,6). Druhá ze signatur pochází opět z majetku Otmara Konrada.

${ }^{56} 1780$, dochováno ve třech exemplárích (KBOR, sig. R-III.a.3044,17, R-III.a.4069,6a a 6b). První signatura pochází z majetku Otmara Konrada, druhé dvě patrně z majetku Bedy Dudíka.

${ }^{57} 1780$ (KBOR, sig. R-Z.e.50, př́iv. 1).

581787 (KBOR, sig. R-III.a.3043a,25a).

${ }^{59}$ Tamtéž, sig. R-Z.e.50, přív. 4, R-III.a.3044,4, R-III.a.4087,7 a R-III.a.3044,2. Dva posledně uvedené tisky byly rovněž v majetku Otmara Konrada.

${ }^{60}$ KBOR, sig. R-III.a.4085,10 a R-VI.b.8818, přív. 6.
} 
spadají ještě jeden tisk litomyšlský - Pjseň $k$ neyswětěgssý Oběti nowozákonné ${ }^{61}$ - a vídeňský. ${ }^{62} \mathrm{Z} 90$. let 18 . století pocházejí v Rajhradě dochované tisky Pjsen̆ ke Mssy swaté z brněnské Hallerovy tiskárny ${ }^{63}$ a Pjseň o Prozřetelnosti Božské z produkce Jana Silvestra Siedlera. ${ }^{64}$

Do 19. století je datováno 23 tisků, u necelé poloviny jsme odkázáni na roky fungování dané tiskárny (Tomáše Tábora v Praze v letech 1835-1847, ${ }^{6}$ brněnské rohrerovské tiskárny vedené vdovou po Rudolfovi Hedvikou v letech $1839-1852^{66}$ a Karla Winikera v letech $1848-1877^{67}$ ).

Dne 26. května 1814 publikoval Václav Hanka svou Pjseň ke cti Geho Milosti Frantisska I. Cýsaře rakauského, Krále uherského, českého, a t.d., ${ }^{68}$ a to v prŕloze Vídeňských novin - Prvotinách pěkných umění. Píseň vyšla taktéž jako samostatný tisk a takto je dochována v rajhradské klášterní knihovně. O pět let mladší je další vídeňský tisk Frommer Gruß!. ${ }^{69}$ Ve 20. letech vyšly u Jana H. Pospíšila (v Hradci Králové a v Praze) Pjsen̆ na slawnost Neyswětěgssjho Gména Gežjšs,... ${ }^{70}$ od Josefa Holáska a Radostná pjseñ k neysladssjmu Gežjssi Josefa Millera. ${ }^{71}$

$\mathrm{Z}$ následujícího desetiletí jsou v rajhradské knihovně dochovány tisky Pjsně $k$ Bohu ${ }^{72}$ vydané nákladem blučinského faráře Václava Pešiny a tištěné opět u J. H. Pospíšila, Pjsně k Božimu Tělu ${ }^{73}$ a Zpěwy o wzkřjssenj Pánē ${ }^{74} \mathrm{z}$ produkce pražské arcibiskupské tiskárny a skalický tisk Pisně pri ročiteg Ružowég Slawnosti w Nádasi, w Swato=Dusni Pondelek Roku 1837 ustanoweneg. ${ }^{75}$

Rokem 1848 je možno datovat tisk Národní hymny. ${ }^{76}$ Poslední dva tisky kramářských písní vyšly v letech $1851^{77}$ a $1852^{78} \mathrm{v}$ Brně.

Většina písní je duchovního obsahu, pouze sedm písniček je věnováno světským tématům. Dva tisky popisují velkou vodu, první v roce 1736 ve východním Frísku ${ }^{79}$ a druhý $\mathrm{v}$ roce $1816 \mathrm{v}$ Městě Albrechtice. ${ }^{80}$ Tři tisky jsou svázány s panovnickým domem - po roce 1809 brněnský tiskař Jan Jiří Gastl přetiskl písně Františka Jana Vaváka popisující vyorání brázdy u Slavíkovic na Vyškovsku Josefem II. v roce $1769,{ }^{81}$ druhý je samostatným tiskem oslavné básně Václava Hanky publikované původně 26. května 1814 v př́loze Vídeňských novin na císaře Františka I. připomínající jeho

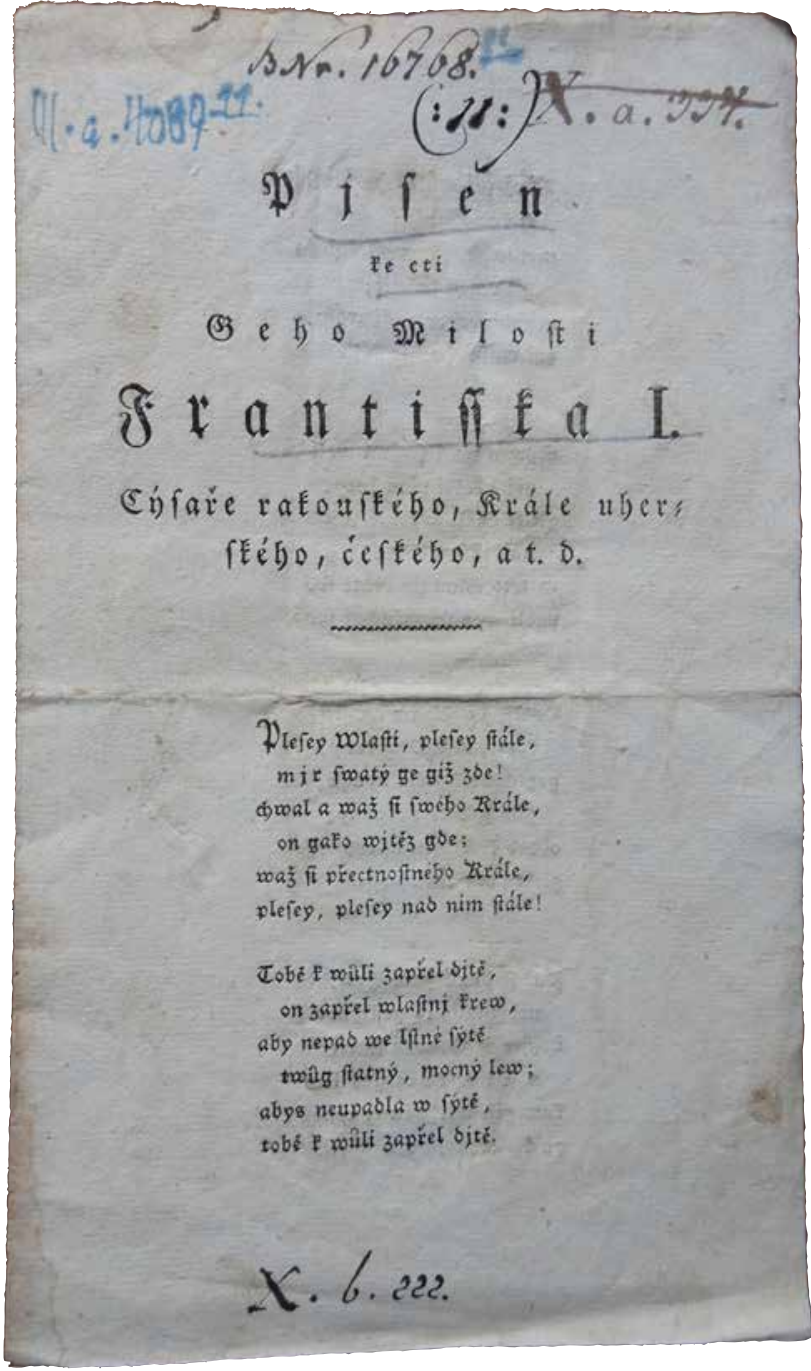

Obr. 3. Začátek písně V. Hanky k oslavě vstupu císaře Františka I. do Pařiže (KBOR, sig. R-III.a.4089,11).

vstup do Paříže $\mathrm{e}^{82}$ a třetí je jednolist s textem Národní hymny oslavující císaře Ferdinanda I. v roce 1848. Jedná se o novou českou verzi Haydnovy písně Zachovej nám Hospodine složenou Václavem Jaromírem Pickem, která reagovala

${ }^{61} 1786$ (KBOR, sig. R-III.a.4087,14).

${ }^{62} 1783$ (KBOR, sig. III.a.3044,3). Tisk pochází z majetku Otmara Konrada.

${ }^{63} \mathrm{KBOR}$, sig. R-III.a.3036,2.

${ }^{64} 1792$ (KBOR, sig. R-III.a.3044,7). Tisk pochází z majetku Otmara Konrada.

${ }^{65}$ Tamtéž, sig. R-III.a.3043a,23, R-III.a.4081,22 a 25.

${ }^{66}$ Tamtéž, sig. R-III.a.4062,33-35 a 48 a R-III.a.4089,20.

${ }^{67}$ Tamtéž, sig. R-III.a.4062,49 a 49, př́iv.

${ }^{68}$ Tamtéž, sig. R-III.a.4089,11.

${ }^{69}$ Tamtéž, sig. R-III.a.4069,5b.

${ }^{70}$ Tamtéž, sig. R-III.a.4062,43.

${ }^{71}$ Tamtéž, sig. R-III.a.4062,36.

72 Tamtéž, sig. R-III.a.4077,25 a R-III.a.4062,41.

${ }^{73}$ Tamtéž, sig. R-III.a.4087,19 a R-III.a.4092,42.

${ }^{74}$ Tamtéž, sig. R-III.a.4062,50.

${ }^{75}$ Tamtéž, sig. R-III.a.4062,38.

${ }^{76}$ Tamtéž, sig. R-III.a.4062,25.

${ }^{77}$ Tamtéž, sig. R-III.a.4062,47.

${ }^{78}$ Tamtéž, sig. R-III.a.4062,32.

${ }^{79}$ Tamtéž, sig. R-III.a.4080,41, přív. 11.

${ }^{80}$ Tamtéž, sig. R-III.a.4084,19.

${ }^{81}$ Tamtéž, sig. R-III.a.4087,17.

${ }^{82}$ Tamtéź, sig. R-III.a.4089,11. 
na události roku 1848, zejména březnový slib ústavy a povolení základních občanských svobod. ${ }^{83}$ Všechny tyto tisky zcela zapadají do zájmu rajhradských řeholníků o politické dění a svět za branami kláštera vůbec. Zatímco ale v první polovině 18 . století byla $\mathrm{v}$ klášteře tendence takovéto tisky či rukopisné zápisky ke světským (většinou politickým) tématům ukládat společně a posléze je i svázat do konvolutu, ${ }^{84}$ pro 19. století byla v tomto ohledu typická spíše roztříštěnost uchování. Jednotlivé tisky byly původně v majetku různých osob a do knihovny se dostávaly v jiných okamžicích, čemuž napovídá i skutečnost, že se dnes nacházejí uložené v rozdílných krabičkách.

Předposledními tisky se světskou tematikou jsou Dwě Pjsně k potěssenj pilným sskolnjm Djtkám ${ }^{85}$ vydané v závěru 18. století v Brně a Branntweinlied ${ }^{86}$ - pijácká píseň oslavující pálenku a popisující výrobu tohoto moku a výhody a prrínosy jeho popíjení - z počátku 19. století.

Všechny ostatní tisky kramářských písní jsou duchovního obsahu. Nejčastěji se jedná o písně k Panně Marii ${ }^{87}$ či písně zpívané při pouti do Mariazell či do baziliky Maria Taferl. ${ }^{88}$ Vedle těchto dvou poutních míst evidujeme v Rajhradě ještě kremžský tisk písní při pouti do baziliky Nanebevzetí Panny Marie ve Wagramu. ${ }^{89}$ Až na sedm písní se všechny tisky s mariánskou tematikou dochovaly v jediném v rajhradské knihovně uloženém špalíčku. Tento špalíček obsahuje výhradně jazykově německé tisky a vedle mariánské tematiky se $\mathrm{v}$ něm setkáváme se dvěma tisky obsahujícími písně k Janovi Nepomuckému, ${ }^{90}$ tiskem o velké vodě ve východním Frísku (viz výše) a duchovními písněmi obecně. Špalíček obsahuje 11 tisků, u kterých nelze určit místo vydání, ale vzhledem $\mathrm{k}$ tomu, že zbylé tisky patří do produkce tiskáren v Brně, Znojmě, Jindřichově Hradci, Kremži, Linci a Vídeňském Novém Městě, je možno místo jejich vzniku hledat rovněž v těchto lokalitách.

Mariazellská tematika je obecně, pokud vezmeme v úvahu i jiné než kramářské tisky, v rajhradském fondu značně rozšířená. Blízkost tohoto poutního místa se odráží v dalších 16 tiscích z 18. a jednom tisku ze 17. století a osmi grafických listech zachycujících Pannu Marii v Mariazell. Za zmínku zde stojí zejména konvolut drobných tisků (kázání, modliteb), ve kterém se tisků s mariazellskou tematikou nalézá šest. ${ }^{91}$ Konvolut bohužel nenese žádnou provenienci, která by nám napověděla, který z bratř́ tisky pro knihovnu pořídil. Zájem o Mariazell lze podle ostatních dochovaných proveniencí přiřknout jen v 18. století bratru Otmarovi, ${ }^{92}$

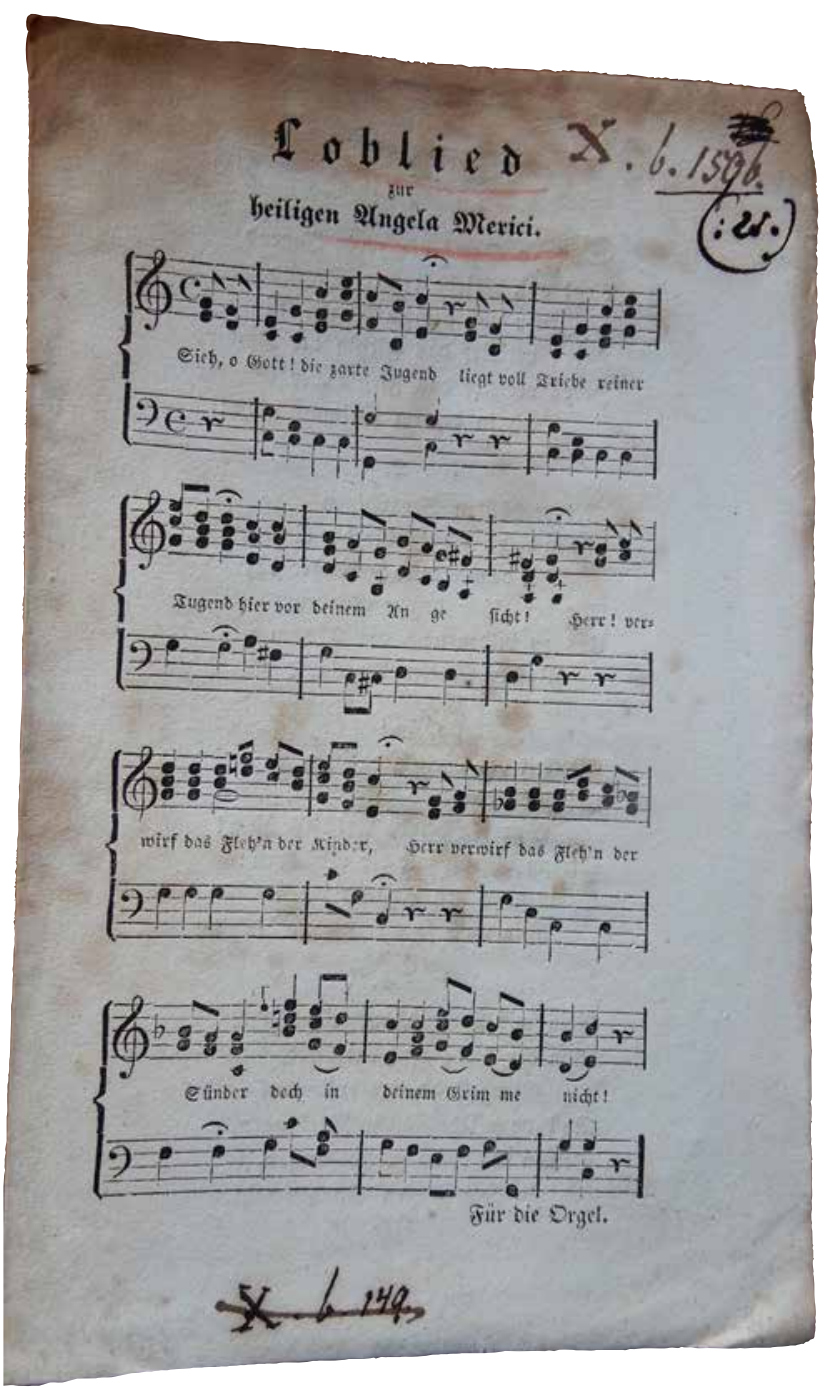

Obr. 4. Úvodní notace z tisku Loblied zur heiligen Angela Merici. Praha: gedruckt bei Thomas Thabor, im Annakloster Arc. 948, [mezi 1835 a 1847]. (KBOR, sig. R-III.a.4081,25).

Mauru Haberhauerovi, ${ }^{93}$ a ve druhé polovině 19. či na začátku 20. století Mauru Kinterovi. ${ }^{94}$

Zbylých sedm mariánských kramářských písňových tisků je českých, jeden - obsahující píseň ke jménu Panny Marie spolu s písní ke jménu Ježíše Krista - byl vytištěn v roce 1768 v Brně u Emanuela Svobody, ${ }^{95}$ druhý - Salve Regina, neb Zdráwas Králowno... ${ }^{96}$ - vyšel v první polovině 19. století, třetí je brněnským tiskem písně k oběti mše svaté,

\footnotetext{
${ }^{83}$ Tamtéž, sig. R-III.a.4062,25. Více k tématu písně viz RAK 2010, s. 261.

${ }^{84}$ Více $\mathrm{k}$ tomu viz pozn. 4.

${ }^{85}$ KBOR, sig. R-III.a.4080,16.

${ }^{86}$ Tamtéž, sig. R-III.a.4090,19.

${ }^{87}$ Písní s mariánskou tematikou evidujeme v souboru 21, z toho osm je jich přímo k Panně Marii Cellenské, pět z nich bylo vytištěno v Brně pro brněnské poutníky účastnící se každý rok poutě do Mariazell. Jedna písnička se obrací na Pannu Marii Šaštínskou.

${ }^{88}$ KBOR, sig.R-III.a.4080,41, přív. 18 a R-III.a.4080,41, přív. 22.

${ }^{89}$ Tamtéž, sig. R-III.a.4080,41, přív. 26.

${ }^{90}$ Tamtéž, sig. R-III.a.4080,41, přív. 5 a R-III.a.4080,41, přív. 17.

${ }^{91}$ Tamtéž, sig. R-E.II.gg.18.

92 Tamtéž, sig. R-R.II.ddd.31.

${ }^{93}$ Tamtéž, sig. R-E.I.c.19, přív. 10.

94 Tamtéž, sig. R-E.II.d.11, přív. 14.

95 Tamtéž, sig. R-III.a.3043a,25b.

96 Tamtéž, sig. R-III.a.4062,44.
} 


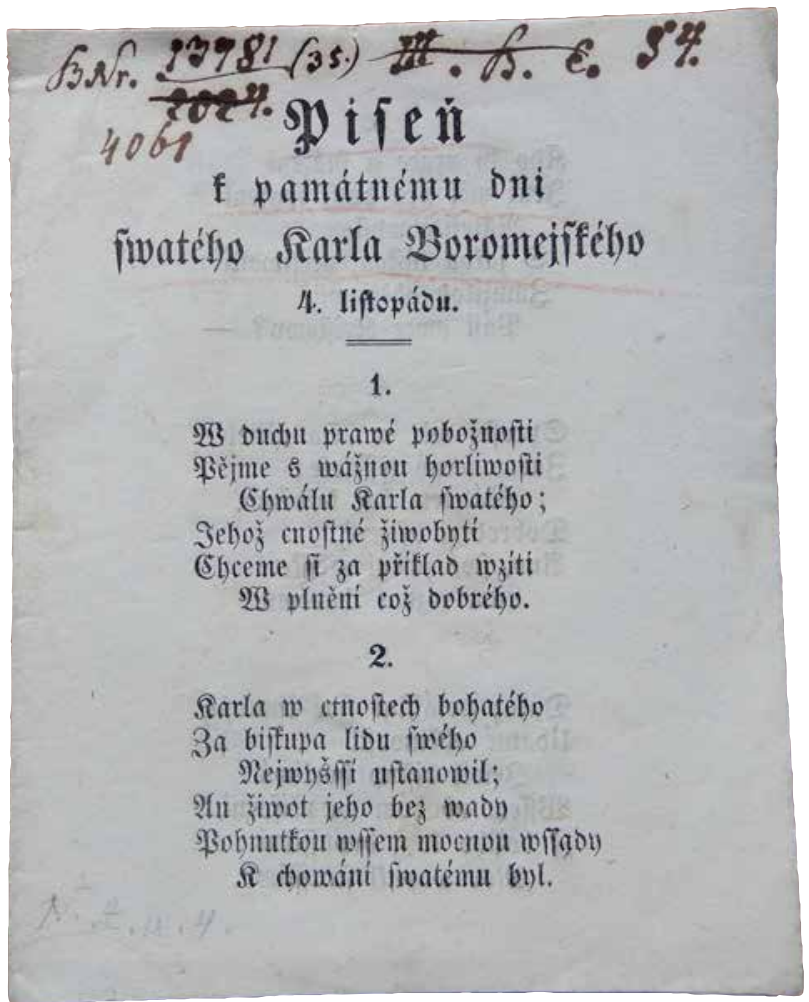

Obr. 5. Tisk Piseň k památnému dni swatého Karla Boromejského 4. listopadu. Brno: tisk vdowy Rudolfa Rohrera, [mezi 1839 a 1852]. (KBOR, sig. R-III.a.4062,35).

který zahrnąuje písně při ranní mši, při požehnání a $\mathrm{k}$ Panně Marii, ${ }^{97}$ čtvrtý vydala Hedvika Rohrerová ${ }^{98}$ a zbylé tři Karl Winiker v Brně. ${ }^{99}$

Hojně je v písních zastoupen rovněž Jan Nepomucký, což je dáno jednak tím, že tyto písně byly obsaženy i ve výše uvedeném špalíčku, ${ }^{100}$ jednak tím, že pět $\mathrm{z}$ těchto tisků se do knihovny dostalo z majetku probošta O. Konrada, respektive jeho otce Víta Jana Nepomuka Konrada. ${ }^{101}$ Poslední rajhradský tisk písně k Janovi Nepomuckému byl vydán ve Znojmě u Antonína Jana Preisse. ${ }^{102}$ Zajímavé jsou také tři dochované tisky písní k zakladatelce voršilek sv. Angele Merici, které byly všechny vydané v tiskárně Tomáše Tábora v Praze. Dva tisky jsou německé ${ }^{103}$ a jeden je český. ${ }^{104} \mathrm{~V}$ rajhradské knihovně se nacházejí i další tři tisky (jeden ve dvou exempláŕích) vážící se k osobě sv. Angely Merici. Jedná se o tisk J. Gastla v Brně Die XXXI. Maji. In festo S. Angelae Mericiae Fundatricis societatis S. Ursulae ${ }^{105}$ a rovněž $\mathrm{v}$ Brně vytištěné zprávy o jejím svatořečení. ${ }^{106}$

$\mathrm{Z}$ dalších světců se v písních setkáváme se sv. Annou, ${ }^{107}$ sv. Františkem Xaverským, ${ }^{108}$ sv. Karlem Boromejským, ${ }^{109}$ sv. Augustinem, ${ }^{110}$ sv. Antonínem Paduánským, ${ }^{111}$ Ignácem z Loyoly ${ }^{112}$ a sv. Peregrinem. ${ }^{113}$

Opominout samozřejmě nesmíme písně obracející se k Ježíši Kristu, ${ }^{114}$ Bohu Otci, ${ }^{115}$ sv. Trojici ${ }^{116}$ či božské prozřetelnosti ${ }^{117}$ a božským ctnostem. ${ }^{118}$ Zajímavé jistě je, že tyto písně větší měrou vycházely až v 19 . století.

Další skupinu tvoří písně vztahující se ke mši svaté119 či křest'anům obecně. ${ }^{120}$

Tři písně mají vztah $\mathrm{k}$ Domašovu, jedné $\mathrm{z}$ farností spravovaných z rajhradského kláštera. Jedná se o píseň Christiana Fürchengotta Gellerta Pjseň o lásce $k$ bližnímu swému: $k$ prospěchu domassowského Institutu chudých, ${ }^{121}$ Pjseñ Bratrů Domassowských aučinliwé lásky bližního ${ }^{122}$ a Gesänge für die domaschower Vereinigung der thätigen Liebe des Nächstens, ... ${ }^{123}$ všechny vytištěné v Brně u Jana Silvestra Siedlera v roce 1784 nebo krátce po něm.

Poslední tisk je produkcí skalické tiskárny a váže se k růžencové slavnosti v obci Trstín na Slovensku. ${ }^{124}$

$\mathrm{Z}$ jazykového hlediska převládají tisky v němčině, to je ovšem dáno zejména dochováním kompletně německého

97 Tamtéž, sig. R-III.a.3044,4.

98 Tamtéž, sig. R-III.a.4062,48.

99 Tamtéž, sig. R-III.a.4062,47, R-III.a.4062,49 a R-III.a.4062,49, přív.

100 Tamtéž, sig. R-III.a.4080,41, přív. 5, R-III.a.4080,41, přív.8 a R-III.a.4080,41, přív. 17.

101 Tamtéž, sig. R-III.a.3044,8a, R-III.a.3044,8b, R-III.a.3044,8c, R-III.a.3044,8d a R-III.a.3044,8e.

102 Tamtéž, sig. R-Z.II.d.40, přív. 3.

103 Tamtéž, sig. R-III.a.3043a,23 a R-III.a.4081,25.

104 Tamtéž, sig. R-III.a.4081,22.

105 Tamtéž, sig.R-R.f.69, přív. 5.

106 NACHRICHT a PIUS 1810.

${ }^{107}$ KBOR, sig.R-III.a.4080,41, přív. 6.

108 Tamtéž, sig. R-Z.e.50, př́v. 2.

109 Tamtéž, sig. R-III.a.4089,16 a R-III.a.4062,35.

110 Tamtéž, sig. R-III.a.3043a,24.

111 Tamtéž, sig. R-H.I.f.26, př́iv.

112 Tamtéž, sig. R-Z.e.50, přív. 1

113 Tamtéž, sig. R-III.a.4062,32.

114 Tamtéž, sig. R-III.a.4069,5a a 5b, R-III.a.4062,43, R-III.a.4062,36, R-III.a.4087,19, R-III.a.4092,41, R-III.a.4062,50, R-III.a.3043a,25b, R-III.a.4080,41, př́v. 6.

115 Tamtéž, sig. R-III.4062,41.

116 Tamtéž, sig. R-III.a.4080,41, př́iv. 7.

117 Tamtéž, sig. R-III.a.3044,7.

118 Tamtéž, sig. R-III.a.4080,17 a R-III.a.3044,6.

119 Tamtéž, sig. R-III.a.3036,2, R-III.a.4062,33 a 34, R-III.a.3044,3, R-III.a.4087,14, R-III.a.3043a,25a.

120 Tamtéž, sig. R-III.a.3044,18, R-III.a.4089,20, R-III.a.3044,17, R-III.a.4069,6a a 6b.

121 Tamtéž, sig. R-III.a.4087,7.

122 Tamtéž, sig. R-III.a.3044,2.

${ }^{123}$ Tamtéž, sig. R-III.a4085,10 a R-VI.b.8815, přív. 6.

124 Tamtéž, sig. R-III.a.4062,38. 
špalíčku, ve kterém je svázáno 29 písniček. Písničky dochované jako přívazky jsou ve dvou případech české a ve dvou německé, jedna z českých písniček je dochována jinak $\mathrm{v}$ kompletně jazykově německém konvolutu.

U písniček datovaných do 18 . století výrazně převažuje němčina, jen pokud zahrneme i písničky ze špalíčku, jinak je jazykově německých a českých písniček z 18. století dochováno stejně (vždy 13 tisků). U století 19. pak jednoznačně převládají kramářské písně v češtině, prričemž z pěti jazykově německých tisků byly dva vytištěny v Praze u Tomáše Tábora, ${ }^{125}$ jeden ve Vídni ${ }^{126}$ a jeden patrně v Jihlavě. ${ }^{127}$ Skalický tisk z roku 1837 je ve slovenštině. ${ }^{128}$ Mezi 19 českými tisky 19. století nalezne jeden tisk z dílny Tomáše Tábora v Praze, ${ }^{129}$ dva tisky pražské arcibiskupské tiskárny ${ }^{130}$ a tři tisky Jana Hostivíta Pospíšila (Praha a Hradec Králové $)^{131}$ a jeden tisk vídeňský ${ }^{132}$ a 12 z brněnských tiskáren Jana Jiř́iho Gastla, Hedviky Rohrerové a Karla Winikera. $\mathrm{V}$ př́padě brněnské písňové produkce zaznamenáváme tedy v rajhradském fondu markantní jazykovou změnu, kdy do té doby jednoznačně převažující písničky v němčině vystřídaly písničky tištěné česky. Pro 18. století jen v rajhradském fondu evidujeme $z$ brněnské produkce 16 tisků v němčině a devět v češtině. Je to však - jak si ukážeme níže - dáno zájmem řeholníků, nikoliv skladbou vlastní tiskařské produkce.

\section{Písňová produkce brněnských tiskáren a její odraz v rajhradské klášterní knihovně}

V závěru této studie bychom se blíže podívali na písňovou produkci z brněnských tiskáren, nebot’ její zastoupení mezi rajhradskými kramářskými písněmi je velmi vysoké. Následující pasáže si však rozhodně nekladou za cíl přinést ucelené poznání o kramářské písňové produkci v Brně, nebot' to je téma na samostatné pojednání. Určující pro formulování závěrů v této oblasti je také fakt, že ucelenější představu si můžeme na základě Soupisu brněnských tisků udělat výhradně pro produkci do roku 1800, která ovšem zdaleka není v uvedené publikaci podchycena $\mathrm{v}$ absolutní úplnosti. ${ }^{133}$

Abychom si udělali představu o brněnské tištěné produkci obecně, uved'me její charakteristiku z pera Vladislava
Dokoupila: „Vyplývá to ostatně i z charakteru této produkce, která byla prece jen na rozdil od jiných velkých měst, a to i od Olomouce jako sídla univerzity a biskupství, mnohem úžeji spjata s potřebami a zájmy města, úřadu a institucí v něm sídlicích a okolních klášterì, pobožných bratrstev, divadelnich společností a několika místních autorů. "134 Tato věta charakterizuje brněnský knihtisk do roku 1800 jako celek naprosto přesně. U výseku kramářských písní bychom do výčtu zákazníků brněnských tiskáren přidali ještě okolní venkovské česky hovořící obyvatelstvo. Zatímco téměř polovina produkce brněnské svobodovské tiskárny za celou dobu jejího trvání byla $\mathrm{v}$ němčině a českých, stejně jako latinských titulů byla cca čtvrtina, ${ }^{135}$ u kramářských písní je v českém jazyce $82 \%$ brněnské produkce do roku 1800 . Z toho je zřejmé, že tento typ tisků nebyl určen pro odběratele prrímo ve městech a ani ve venkovských klášterech, ale cílil konkrétně na jazykově české obyvatelstvo v brněnském okolí.

Jazykově německý je tisk o královské korunovaci sepsaný Thomasem Hoffmannem v roce 1620 a vytištěný Christophem Haugenhofferem, ${ }^{136}$ Christlicher Reimblein vydaný po roce $1705,{ }^{137}$ písničky k Janu Nepomuckému, ${ }^{138}$ Panně Marii Cellenské či týkající se poutě do Mariazell, ${ }^{139}$ Marii Taferl ${ }^{140}$ a Ignácovi z Loyoly. ${ }^{141} \mathrm{~V}$ němčině byly také vydány zpěvy ke mši svaté, ${ }^{142}$ zpěvy pro domašovský institut, ${ }^{143}$ velikonoční písen ${ }^{144}$ a obecné křest'anské písně. ${ }^{145}$ Pouze dva z těchto německých tisků se dnes nenachází v rajhradském knihovním fondu. Nutno ovšem podotknout, že většina tisků je v Rajhradě dochována v onom jazykově německém špalíčku a dalších šest písniček se do fondu dostalo bud' z majetku Otmara Konrada, nebo Bedy Dudíka. Otmar Konrad se narodil v jazykově německých Ivančicích a dotčené tisky patrně pocházely z majetku jeho otce, Beda Dudík pak plynně německy hovořil.

Zlomem v jazyce písňových tisků v rajhradském fondu jsou 80. léta 18. století. Až na jeden německý tisk vztažený k Domašovu, jsou všechny tisky již pouze české. A tento trend pokračuje i v první polovině 19. století, kdy všechny tisky brněnských tiskáren dochované v rajhradské knihovně J. J. Gastla, Hedviky Rohrerové a K. Winikera jsou v češtině.

Jazykově česká brněnská písňová produkce je z hlediska tematiky výrazně rozmanitější. Rovněž se zde setkáme

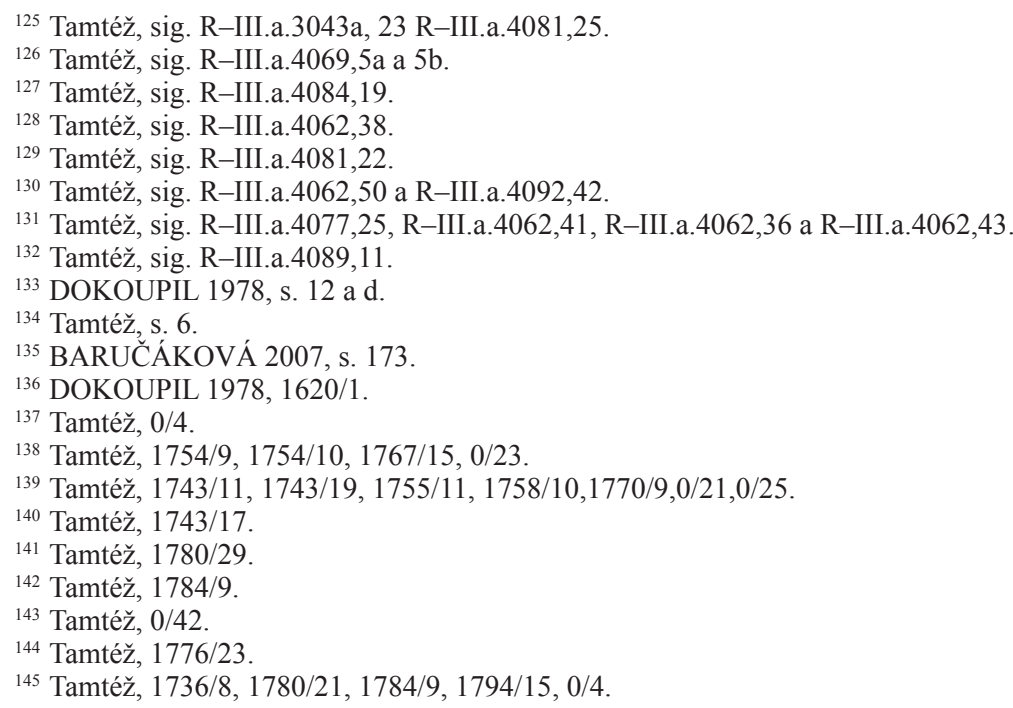


s obecně křest'anskými písněmi, is písněmi k Panně Marii, vedle P. Marie Cellenské, se však objevuje i P. Marie Žarošická, ${ }^{146}$ P. Marie Tuřanská, ${ }^{147}$ P. Marie Vranovská, ${ }^{148}$ P. Marie Křtinská, ${ }^{149}$ P. Marie Svatohorská ${ }^{150}$ a P. Marie Šaštínská ${ }^{151}$ a Čenstochovská. ${ }^{152}$ Mezi světci je nejhojněji opět zastoupen Jan Nepomucký, ale rovněž zde nalezneme písničky k Janu Sarkanderovi, ${ }^{153}$ sv. Anně, ${ }^{154}$ Sv. Florianovi, ${ }^{155}$ sv. Tekle, ${ }^{156}$ sv. Kateřině, ${ }^{157}$ sv. Augustinovi ${ }^{158}$ či sv. Josefovi. ${ }^{159}$ Od 80 . let 18. století se také i mezi brněnskými tisky v rajhradském fondu objevují v podobě drobných - kramářských - tisků písně ke mši svaté.

Pouze čtyři brněnské tisky se věnují světské tematice, a to německý tisk ke královské korunovaci z roku $1620^{160}$ a české tisky Žalostná a př́kladná Nowina kteráž se stala w Vherském Králowstj [sic!]. W Městě Eperges, ${ }^{161}$ Nowina gistá a prawdiwá, kterak tohoto Roku geden Ožracel w Sstayermarku po půl Nocy z Hospody přes Krchow domu gdauce, ... ${ }^{162}$ a Sprawa Prawdiwa w Rytmy vwedená, O přehrozném Země-třesenj, Které se stalo w Králowstwj Sycyligi, $w$ rečeném Městě Palermo, ... ${ }^{163}$

Jazyk tisku jednoznačně před rokem 1800 ovlivňoval i jeho podobu. České písničky mají téměř výhradně šestnácterkový formát, ve starším období výhradně s osmi listy, posléze se rozsah ustaluje na čtyřech listech. Německé tisky mají od počátku (až na tisk z roku 1620) osmerkový formát a až na mešní zpěvy rozsah dva listy. Mešní zpěvy v obou jazycích mívají od osmi do 16 listů. Od 80. let 18. století pak osmerkový formát více nastupuje i u českých tisků, šestnácterka zůstává tam, kde tiskárna navazuje na starší tisk. To také ovlivňuje skutečnost, že všechny v Rajhradě identifikované kramářské písně mají osmerkový formát.

\section{Závěr}

V rajhradském benediktinském fondu je dnes uloženo 81 písňových tisků, které můžeme zařadit mezi písně kramářské. Většina z nich je uložena v krabičkách, které jsou typické pro uchování drobných tisků z klášterní knihovny, jež se do ní dostaly v průběhu 19 . století. Na předchozích řádcích jsme se pokusili zodpovědět otázku, kdy a jak se kramářské písně do knihovny dostávaly - tedy z majetku kterého řeholníka. Závěry v této oblasti nám bohužel dnes umožňuje pouze několik málo provenienčních prŕípisků, které ani nejsou přímo na dotčených kramářských tiscích, ale tiscích, které jsou s nimi v krabičkách uložené. I tak se nám ale podařilo identifikovat skupinu 13 tisků, které se do knihovny dostaly zásluhou posledního probošta Otmara Konrada. Stejně tak se nám podařilo dva $\mathrm{z}$ tisků spojit se jménem Bedy Dudíka. Analýza dále ukázala, že téměř polovina tisků vznikla z některé $\mathrm{z}$ brněnských tiskáren, dále je zastoupena písňová produkce z Prahy, Hradce, Králové, Jindřichova Hradce, Litomyšle, patrně Jihlavy, Znojma, Vídně, Vídeňského Nového Města, Lince, Kremže a Skalice. Oproti převažujícím tiskům brněnským jsou však ostatní místa vydání zastoupena pouze jednotlivinami. Téměř u čtvrtiny tisků nelze místo vydání přesně určit a stejně tak jejich datace zůstává omezena na průběh 18. století.

Převážná většina písní je duchovního obsahu, pouze sedm tisků se věnuje světskému tématu. V jazyce tisků jednoznačně převažuje němčina, ale $\mathrm{v}$ pravdě jen proto, že jediný dochovaný špalíček sestává kompletně z německých písní. V 80. letech 18. století se pomyslný jazýček na vahách v rámci jazyků vychýlí ve prospěch češtiny. Jediný skalický tisk v souboru je ve slovenštině.

Otázka, na kterou ovšem neumíme ani po výše uvedené analýze tisků odpovědět, ovšem zní, zda byly popsané tisky skutečně používány, zda uvedené písně jejich majitelé skutečně zpívali, nebo zda si pouze tisky pořídili či je dostali v tiskárně spolu s jinými tituly, a nikdy je nevyužili k jejich primárnímu určení (at' již to byla osobní zbožnost, zpěv v procesích či při poutích, nebo i kolektivní zpěv v kostele). Pouze jediný dochovaný špalíček nám na tuto otázku umí dát kladnou odpověd', a to zejména formou svého dochování, ze které je patrné značné opotřebení tisků jejich užíváním. Neznáme sice majitele špalíčku, můžeme ovšem konstatovat, že to byl jazykově Němec, snad některý z řeholníků či z jejich rodinných příslušníků, který žil mezi druhou a třetí čtvrtinou 18. století (alespoň do této doby lze zasadit vznik všech datovaných tisků ze špalíčku), který podnikl nejednu pout' do Mariazell a do baziliky Maria Taferl či do Wagramu. Ostatně jím sestavený špalíček významně obohatil rajhradské kramářské písně právě o tisky ze Znojma, Jindřichova Hradce, Kremže a Vídeňského Nového Města.

U ostatních písniček bohužel otázku používání zodpovědět neumíme. Zbylé tisky nejsou poškozeny opotřebením, většina tisků 19. století vypadá spíše netknutá. Zůstává tedy

\footnotetext{
146 Tamtéž, 1708/6, 1739/16, 1753/10.

147 Tamtéž, 1709/6.

148 Tamtéž, 1745/10, 1764/18.

149 Tamtéž, 1781/28, 1784/9, 0/125.

150 Tamtéž, 1717/24.

151 Tamtéž, 1734/16.

152 Tamtéž, 1755/16.

153 Tamtéž, 1704/8, 1708/9.

154 Tamtéž, 1730/23, 1764/19, 0/58.

155 Tamtéž, 1745/9.

156 Tamtéž, 1753/11.

157 Tamtéž, 1773/13.

158 Tamtéž, 1776/13.

159 Tamtéž, 1778/25.

160 Tamtéž, 1620/1.

161 Tamtéž, 1716/15.

162 Tamtéž, 1717/23.

163 Tamtéž, 1727/21.
} 
otázkou, zda podle nich majitel skutečně zpíval, či zda si je pouze pro zajímavost zakoupil, nebo je někde dostal (například v některé $\mathrm{z}$ brněnských tiskáren při pořízení jiného titulu).

\section{Bibliografický soupis}

Acht schöne neue Geistliche Lieder. Das Erste: Aus dreyen schönen Blümelein, will ich etc. Das Anderte: O St. Johann von Nepomuck, glückseelig etc. Das Dritte: Verehret alle Zungen, Johannis reinen etc. Das Vierdte: Stille Zungen überwunden, hab darum etc. Das Fünffte: Wie stehts doch in der Welt? es steht etc. Das Sechste: Verblendte Welt thu sagen, was hat dich etc. Das Siebende: Jetzt trau ich keinen Menschen mehr, etc. Das Achte: Flüchtige Zeit, verflossene Freud, etc. [Česko?: nakladatel není známý, mezi 1710 a 1787?]. KBOR, sig. R-III.a.4080,41, př́v. 17

Anmütiges Gesang zu dem Heil. Johann von Nepomuck. Znaym: Gedruckt bey Anton Johann Preyß privil. Buchdrucker, [mezi 1743 a 1787]. Dostupné z: http://imageserver.mzk.cz/mzk03/001/181/987/328100206061.titul3. KBOR, sig. R-Z.II.d.40, př́v. 3

Beschreibung der grossen Wasserfluth, welche sich im Jahre 1816 den 26. 27. 28. und 29. August durch vier Tage und drey Nächte zu Olbersdorf in kais. Schlesien zugetragen hat. [Jihlava: Fabián Beinhauer?, mezi 1816 a 1820?]. Vydání je typograficky rozdílné od toho z roku 1813, které J. Vobr řadí do Jihlavské Beinhauerovy tiskárny. KBOR, sig. R-III.a.4084,19

Branntweinlied. [Česko?: nakladatel není známý, mezi 1801 a 1825?]. KBOR, sig. R-III.a.4090,19

[Čtyři duchovní písnē]. [Česko?: nakladatel není známý, mezi 1710 a 1787?]. KBOR, sig. R-III.a.4080,41, přív. 1

[Čtyři duchovní písnē]. [Česko?: nakladatel není známý, mezi 1710 a 1787?]. KBOR, sig. R-III.a.4080,41, přív. 2

[Duchovní písnē]. [Česko?: nakladatel není známý, mezi 1710 a 1787 ?]. KBOR, sig. R-III.a.4080,41, přív. 14

[Dvě písně k Panně Marii Šaštínské]. [Česko?: nakladatel není známý, mezi 1710 a 1787?]. KBOR, sig. R-III.a.4080,41, přív. 10

Drey schöne gantz neue Kirchfahrt-Lieder, Von dem neuen Gnaden-Orth zu Kirchberg am Wagram. Das Erste, Ach Freud, ach Freud, O grosse Freud, weil einmahl etc. Crembs: gedruckt bey Ignaz Anton Präxl, [mezi 1732 a 1766?]. KBOR, sig. R-III.a.4080,41, př́v. 26

Drey schöne Geistliche Lieder. [Česko?: nakladatel není známý, mezi 1710 a 1787?]. KBOR, sig. R-III.a.4080,41, př́v. 12 Drey schöne neue Geistliche Lieder Von dem Gegeißleten Heiland auf der Wieß. ZNAYM: Gedruckt bey Anton Joh. Preyß priv. Buchd., [mezi 1743 a 1787?]. KBOR, sig. R-III.a.4080,41, přív. 25

Drey schöne neue Geistliche Lieder, Das Erste: Seyd getröstet alle Sünder, weil nun kommen ist die Zeit, etc. Im Thon: Maria wir fallen dir alle zu Füssen. Das Anderte: Ein Begrüssung zu Maria Zell dem Gnaden-Ort. Das Dritte: Zu der Hoch-heiligen Frauen S. ANNA, Ein Mutter der allerseeligsten Jungfrauen und Mutter GOttes Maria, und ein Ahn-Frau Christo JEsu, ein Schutz-Frau aller Noth-leydenden Christen, und aller mit Leibs-Frucht beladenen Frauen, eine von Christo JESU aller Sterbenden, wider die böllischen Geister Verheisserin, die sie in Leb-Zeiten verehren, starcke Verfechterin. Gedruckt zu Crembs: bey Johann Jacob Ko[pitz], [mezi 1710 a 1729?]. KBOR, sig. R-III.a.4080,41, přív. 6

Drey schöne neue Zeller-Lieder. Das Erste: Nun so bin ich kommen an, O Königin, etc. Das Anderte: Mariam wir loben, wir loben Mariam, etc. Das Dritte: O Maria, ach was Schmertzen, ach was, etc. Neustadt: gedruckt bey Samuel Müller, [mezi 1717 a 1757?]. KBOR, sig. R-III.a.4080,41, přív. 15

Di̊stogný kněz. [Brno]: Tisk wdowy R. Rohrera, [mezi 1839 a 1852]. KBOR, sig. R-III.a.4089,20

Dvě nowé Pjsničky: Prwnj o presladkém Gménu MARYE PANNY, Druhá o neysladssým Gmenu Pána GEŽJSSE. Wytisstěná w Brně: [Emmanuel Svoboda], 1768. DOKOUPIL 1978, 1768/18; VOBR 2005, č. 2206; Knihopis neuvádí. KBOR, sig. R-III.a.3043a,25b

Dwě nábožné Pjsně k neyswětěgssi Oběti Msse swaté: kteréž při Rannj Mssy swaté se vžjwati mohau. Též dwě k swatému Požehnánj, a třetj k Panně Marygi. [Brno: nakladatel není známý, mezi 1780 a 1800]. DOKOUPIL 1978, 0/126; VOBR 2005, č. 2162 (tisk řadí do Jihlavy); Knihopis neuvádí. KBOR, sig. R-III.a.4087,15, R-III.a.3044,4

Dwě Pjsně k potěssenj pilným sskolnjm Djtkám. [Brno: nakladatel není známý, mezi 1780 a 1810]. DOKOUPIL 1978, neuvádí; VOBR 2005, č. 2134; Knihopis neuvádí. KBOR, sig. R-III.a.3044,5, R-III.a.4080,16

Ein betrübte Neue Zeitung, Von erschröcklichen WasserGüssen: So in dem 1736. Jahr entstanden seyn, weilen das Meer in Ost-Frißland in Ditmarschen aus seinen Stand getretten, davon alle Wässer angefüllet worden, dadurch viel Städt und Dörffer ruiniret worden, auch viel tausend Menschen und Vieh, nebst anderen Sachen zu Grund gangen; In Schlesien, Böheim, und Oesterreich, auch anderen Ländern mehr, wie es infolgenden Gesang wird zu vernehmen seyn. Das Anderte: Ein trauriges Exempel, welches sich zu Engedein in Cur, mit einer armen Wittib zugetragen. [Česko?: nakladatel není známý, 1736?]. KBOR, sig. R-III.a.4080,41, př́v. 11 Ein Osterlied: Zum Gebrauche der K.K. Brünner Kathedral Kiche, und der ganzen Brünner Diöces. Brünn: gedruckt bey den Swobodischen Erben, 1778. DOKOUPIL 1978, 1778/23; BCBT, č. 29385. Provenience: Z majetku Otmara Konrada. KBOR, sig. R-III.a.3038,1

Frommer Gruß: Gelob sey Jesus Christus! Angewendet auf dem täglichen Lebenswandel. Wien: [nakladatel není známý], 1819. KBOR, sig. R-III.a.4069,5a, R-III.a.4069,5b

Fünff schöne Neüe Andächtige Lieder Zu dem Heiligen Johannes von Nepomuck. Neü-Hauß: gedruckt bey Johann F. Jackesch, [mezi 1719 a 1732?]. KBOR, sig. R-III.a.4080,41, př́iv. 8

Geistliches Lied, Denen armen Seelen in dem Fegfeuer zu Trost, nach verrichtem Heil. Creutz-Weeg zu singen. Lintz: gedruckt bey Johann Auinger, [mezi 1733 a 1774?]. KBOR, sig. R-III.a.4080,41, prŕiv. 24

Geistliches Zeller-Lied: Im Thon: Auf auf behertzt zum Streiten, etc. Brünn: gedruckt bey denen Jacob Maxim Swobodischen Erben, 1743. DOKOUPIL 1978, 1743/19; BCBT, č. 36458. KBOR, sig. R-III.a.4080,41, přív. 20 GELLERT, Christian Fürchtegott. Pjseň o lásce $k$ bližnímu swému: k prospéchu domassowského Institutu chudých. 
[Brno: Jan Silvestr Siedler, 1784]. DOKOUPIL 1978, 1784/25; VOBR 2005, č. 896; Knihopis neuvádí, popis uveden u č. K02652. Provenience: Z majetku Otmara Konrada. KBOR, sig. R-III.a.30444, R-III.a 4087,7

Gesang Eines sich dem Willen Gottes ergebenden Christens. Brünn: gedruckt bey den Swobodischen Erben, durch Johann Siedler, Faktorn, 1780. DOKOUPIL 1978, 1780/21; BCBT, č. 26792. Provenience: Z majetku Otmara Konrada. KBOR, sig. R-III.a.3044,17, Provenience: Z majetku Bedy Dudíka. R-III.a.4069,6a, R-III.a.4069,6b

Gesang von Dem Heiligen Joanne Von Nepomuck. Gedruck zu Brünn: bey Emmanuel Swoboda, privilegierten Buchdrucker, 1754. DOKOUPIL 1978, 1754/9; BCBT, č. 26793. Provenience: Z majetku Otmara Konrada. KBOR, sig. R-III.a.3044,8b

[Gesang zum Heil. Johannes von Nepomuk]. [Brno: nakladatel není známý, kolem 1754]. DOKOUPIL 1978, 0/23; BCBT, Č. 26795. Provenience: Z majetku Otmara Konrada. KBOR, sig. R-III.a.3044,8a

[Gesang zum Heil. Johannes von Nepomuk]. Gedruck zu Brünn: bey Emmanuel Swoboda, privilegierten Buchdrucker, 1754. DOKOUPIL 1978, 1754/10; BCBT, č. 26795. Provenience: $\mathrm{Z}$ majetku Otmara Konrada. KBOR, sig. R-III.a.3044,8d [Gesang zum Heil. Johannes von Nepomuk]. Znaym: gedruckt bey Anton Joh. Prey $\beta$, 1757. Provenience: Z majetku Otmara Konrada. KBOR, sig. R-III.a.3044,8e

Gesänge für die domaschower Vereinigung der thätigen Liebe des Nächstens, nach der allgemeinen Kirchen=Melodie zum Gottesdienstlichen Gebrauch in ihren Versammlungen vor und nach der heiligen Meße eingericht. Brünn: Gedruckt bei Johann Sylvester Siedler, [mezi 1784 a 1798]. DOKOUPIL 1978, 0/42; BCBT, č. 26789. KBOR, sig. R-III.a.4085,10, R-VI.b.8818, př́ív. 6

Gesänge zum Amte der heiligen Messe samt dem Gesange vor der Predigt. Brünn: gedruckt mit Siedlerischen Schriften, 1784. DOKOUPIL 1978, 1784/9; BCBT; č. 26790. Dostupné z: http://imageserver.mzk.cz/ mzk03/001/181/259/328100204057.titul4. KBOR, sig. R-Z.e.50, přív. 4

HANKA, Václav. Pjseň ke cti Geho Milosti Frantisska I. Cýsaře rakauského, Krále uherského, českého, a t.d. [Vídeň: Wiener Zeitung, 1814]. KBOR, sig. R-III.a.4089,11

HOLÁSEK, Josef. Pjseň na slawnost Neyswětěgssjho Gména Gežjš, z messnjho misálu přeložena od Jozefa Holaska, faráře Blanského bljž Brna. W Hradcy Králowé: Wytisstěna u Jana H. Pospissila, biskupského impressora a aučinkugjcýho auda Českého národního Muzeum, 1828. KBOR, sig. R-III.a.4062,43

Christliche Reimblein Und Auffmunterung de $\beta$ Sünders zur zeitlichen Buß. [Brno?: nakladatel není známý, ne před 1705]. DOKOUPIL 1978, 0/4; BCBT, č. 29940. Provenience: $\mathrm{Z}$ majetku Otmara Konrada. KBOR, sig. R-III.a.3044,18

Chwalozpěw k Angele Meriči. Praha: Tisstěná u Tomásse Tábora, Cjsslo 948, [mezi 1835 a 1847]. KBOR, sig. R-III.a.4081,22

Jährliche Danck-Müntz Von der Königl. Stadt Brünn Bey Gewöhnlicher Wallfahrt Nacher Zell MARIAE Der Himmels-Königin abgezinset. Brünn: gedruckt bey denen
Jacob Maxim. Swobodischen Erben, durch Wentzel Lenhart, Factorn, 1743. DOKOUPIL 1978, 1743/11; BCBT, č. 25920. KBOR, sig. R-III.a.4080,41, přív. 19

Lob-Gesang und Bitte der Marianischen Diener, und Dienerinnen von Brünn auf derselben Wallfahrt nach Maria Zell. Brünn: gedruckt bey Emmanuel Swoboda, privilegirten Buchdruckern, 1770. DOKOUPIL 1978, 1770/9; BCBT, č. 28446. KBOR, sig. R-III.a.4080,41

Lobgesang welches zu ehren des heiligen Vaters Ignazius von Lojola durch die 10 Sonntägige Andacht nach der Melodey des Aloysianischen Lobgesangs: Aloysio zu Ehren, vor der Welt sein Lob zu mehren \&c. Abgesungen wird. Brünn: gedruckt bei den Swobodischen erben, 1780. DOKOUPIL 1978, 1780/29; BCBT, č. 28447. Dostupné z: http://imageserver.mzk.cz/mzk03/001/181/254/328100204057.titul1. KBOR, sig. R-Z.e.50, př́iv. 1

Lob-Gesang zu Ehren des heiligen Johann v. Nepomuck: Welches zu Brünn ob dem Petersberg andächtig gesungen wird. Brünn: gedruckt bey Emmanuel Swoboda, privil. Buchdrucker, 1767. DOKOUPIL 1978, 1767/15; BCBT, č. 28449. Provenience: Z majetku Otmara Konrada. KBOR, sig. R-III.a.3044,8c

Lobgesang zur heiligen Angela Merici. [Praha: Tomáš Tábor, mezi 1835 a 1847]. KBOR, sig. R-III.a.3043a,23

Loblied zur heiligen Angela Merici. Praha: gedruckt bei Thomas Thabor, im Annakloster Arc. 948, [mezi 1835 a 1847]. KBOR, sig. R-III.a.4081,25

MARIA Jn Jhrer Gnaden-Zell Als Eine Allgemeine HülfMutter In allen Widerwärtigkeiten und Nöthen Von Der alljährig-Brünnerischen Gelübds-Wallfahrt verehret. Brünn: bey Emmanuel Swoboda, 1758. DOKOUPIL 1978, 1758/10; BCBT, č. 28614. KBOR, sig. R-III.a.4080,41, př́iv. 28 MARIA Jn Jhrer Gnaden-Zell Dem alljärlich Brünnerischen Wallfahrter Ein Sicherer Weeg zur Seeligkeit. Gedruckt zu Brünn: bey Emmanuel Swoboda, privilegirten Buchdrucker, 1755. DOKOUPIL 1978, 1755/11; BCBT, Č. 28616. KBOR, sig. R-III.a.4080,41, přív. 27

MARIA Jn Jhrer Gnaden-Zell Der alljährlich Brünnerischen Wallfahrt Ein wahrer Trost der Betrübten. Gedruckt zu Brünn: bey Emanuel Swoboda, privilegirten Buchdrucker, 1753. DOKOUPIL 1978, 1753/7; BCBT, č. 28617. KBOR, sig. R-III.a.4080,41, př́v. 23

MARIA Jn Jhrer Granden-Zell Als eine Glück, und Heyl bringende Morgen-Röthe Bey der alljährigen Wallfahrt von der Königlichen Stadt Brünn verehret. [Česko?: nakladatel není známý, mezi 1710 a 1787?]. DOKOUPIL 1978, 0/25; BCBT, Č. 28615. KBOR, sig. R-III.a.4080,41, přív. 16 [Mariánské písnē]. [Česko?: nakladatel není známý, mezi 1710 a 1787?]. KBOR, sig. R-III.a.4080,41, přiv. 13

MILLER, Josef. Radostná pjseň $k$ neysladssjmu Gežjssi (Podle sw. Bernarda:) „Jesu dulcis memoria etc.“ Mel. od Fr. Al. Wacka, Děk w Kopidlně ; Text od J. Millera, Kapl. $w$ Welissi. W Hradcy Králowé a w Praze: Nákladem Jana H. Pospjssila, 1829. KBOR, sig. R-III.a.4062,36

Nábožná Pjseň we wsseobecných potřebách k Marii Panně. Brno: Tiskem C. Winikera, [mezi 1848 a 1877?]. KBOR, sig. R-III.a.4062,49, př́iv.

Národni hymna. [Česko: nakladatel není známý], 1848. KBOR, sig. R-III.a.4062,25 
Neu-voller Seuftzer Zu GOTT, Und seiner Schmertzhasten Mutter in Taferl. Brünn: gedruckt bey denen Jacob Maxim. Swobodischen Erben, 1743. DOKOUPIL 1978, 1743/17. KBOR, sig. R-III.a.4080,41, př́v. 18

Nowá Pjseň k Panně Marii. Brno: Tisk Karla Winikera, 1851. KBOR, sig. R-III.a.4062,47

Piseň k památnému dni swatého Karla Boromejského 4. listopadu. Brno: tisk vdowy Rudolfa Rohrera, [mezi 1839 a 1852]. KBOR, sig. R-III.a.4089,14, R-III.a.4062,35

Pisen̆ o sw. Peregrinu: (Při swěceni obnowene kaply sw. Peregrina we farnosti Ořechowske, léta Páně 1852). Brno: Tisk dědiců Rud. Rohrera, 1852. KBOR, sig. R-III.a.4062,32 Pjseň Bratrů Domassowských aučinliwé lásky bližnjho. [Brno: Jan Silvestr Siedler, 1784]. DOKOUPIL 1978, 0/43; VOBR 2005, č. 1919; Knihopis neuvádí. Provenience: Z majetku Otmara Konrada. KBOR, sig. R-III.a.3044,2

Pjseň k neyswětěgssý Oběti nowozákonné. W Litomyssli: Wytisstěná v Wáclawa Turetschka, 1786. VOBR 2005, č. 2083; Knihopis neuvádí. KBOR, sig. R-III.a.4087,14

Pjseň k S. Antonínu Paduanskému. [Praha: nakladatel není známý, mezi 1741 a 1760]. VOBR 2005, č. 1904; Knihopis neuvádí. KBOR, sig. R-H.I.f.26, př́ív.

Pjsen̆ k swatému Srdci neyblahoslaweněgssj Panny Marie. Brno: tiskem vdowy R. Rohrera, [mezi 1839 a 1852]. KBOR, sig. R-III.a.4089,16, R-III.a.4062,48

Pjsen̆ ke Mssi Swate: kteráž se w hlawným Městě Wjdni podle Cýsařo-králowských Nařjzenj we farnjch Kosteljch spjwá. Witjsst'ena we Wjd’ňi: v Jána Tomasse z Trattnerů, 1783. Dostupné z: http://books.google.cz/books?vid=NKP:1002290565-003\&printsec =frontcover. VOBR 2005, č. 2080; Knihopis, K11807. Provenience: Z majetku Otmara Konrada. KBOR, sig. R-III.a.3044,3

Pjseň ke Mssy swaté. Wytisstěná, a k dostánj w Brně: v Leopolda Frantisska Hallera, w sedlářské Vlicy, [mezi 1793 a 1800]. DOKOUPIL 1978, 0/124; VOBR 2005, č. 2079; Knihopis neuvádí. KBOR, sig. R-III.a.3036,2

Pjsen̆ ku Panně Marii. Brno: Tiskem C. Winikera, [mezi 1848 a 1877 ?]. KBOR, sig. R-III.a.4062,49

Pjseň o Božských Ctnostech. Wytisstěné w Brně: v Dědicůw Swobodských, za Jana Siedlera, Faktora, [1778?]. DOKOUPIL 1978, 0/34; VOBR 2005, č. 1909; Knihopis neuvádí. Provenience: Z majetku Otmara Konrada. KBOR, sig. R-III.a.4080,17, R-III.a.3044,6

Pjseň o Prozretelnosti Božské: Ku Koncy odpolednjch Služeb Božjch. W Brně: wytisstěná v Jána Sylwestra Siedlera, 1792. DOKOUPIL 1978, 1792/23; VOBR 2005, č. 1907; Knihopis neuvádí. Provenience: Z majetku Otmara Konrada. KBOR, sig. R-III.a.3044,7

Pjseň o Sw. Augustinu. [Brno]: Wytisstěno v Emmanuele Swobody, 1776. DOKOUPIL 1978, 1776/13; VOBR 2005, č. 1905; Knihopis neuvádí. KBOR, sig. R-III.a.3043a,24

Pjseň při Požehnánj s neyswětěgssj Swátosti Oltářnj: Zpívá se gako: Pokleknj na kolena. W Brně: w nákladě v Jana Siedlera, měsststkého Impressora, [1787]. DOKOUPIL 1978, 0/45; VOBR 2005, č. 2117; Knihopis neuvádí. KBOR, sig. R-III.a.3043a,25a

Pjseň při požehnánj s neyswětěgssj swátostj oltářnj. Brno: tisk vdowy R. Rohrera, [mezi 1839 a 1852]. KBOR, sig. R-III.a.4062,33
Pjseň u křjže misionárnjho. Brno: tisk vdowy R. Rohrera, [mezi 1839 a 1852]. KBOR, sig. R-III.a.4062,34

Pjsně k Bohu. Blučina: Nákladem Wáslawa Pessiny, faráře blučinského na Moravě, 1831. KBOR, sig. R-III.a.4077,25, R-III.a.4062,41

Pjsně k Božjmu Tělu. W Praze: W knjžecj arcibiskupské knihtiskárně, 1834. KBOR, sig. R-III.a.4087,19, R-III.a.4092,42

[Písně k Panně Marii Cellenské]. [Česko?]: [nakladatel není známý], [mezi 1710 a 1787?]. KBOR, sig. R-III.a.4080,41, př́iv. 9

Pisně pri ročiteg Ružowég Slawnosti w Nádasi, w SwatoDusni Pondelek Roku 1837 ustanoweneg. Witlačené w Skalici: [nakladatel není známý], 1837. KBOR, sig. R-III.a.4062,38

Reumütiges Zins-Opfer, Welches die gesammte BrünnerKirchfährter fußfallend ablegen An dem Schmertzhafften Gnaden-Ort Der Ubergebenedeytesten Jungfrauen Und Mutter GOttes Maria-Tafferl. Brünn: bey denen Jacob Maximilian Swobodischen Erben, 1746. DOKOUPIL 1978, 1746/12; BCBT. č. 36607. KBOR, sig. R-III.a.4080,41, př́v. 22

Salve Regina, neb Zdráwas Králowno: Pjseň k Rodičce Božj. [Česko: nakladatel není známý, mezi 1801 a 1850]. KBOR, sig. R-III.a.4062,44

Der die Schmertzen JEsu und Mariae Betrachtende, Um Gnad bey denenselben anflehende Wallfahrter. Brünn: gedruckt bey denen Jacob Maxim Swobodischen Erben, [mezi 1743 a 1752?]. DOKOUPIL 1978, 0/21; BCBT, č. 37544. KBOR, sig. R-III.a.4080,41, př́v. 21

[Tři duchovní písně o svatém Janu Nepomuckém]. [Česko?: nakladatel není známý, mezi 1710 a 1787?]. KBOR, sig. R-III.a.4080,41, př́v. 5

[Tři duchovní písnē]. [Česko?: nakladatel není známý, mezi 1710 a 1787?]. KBOR, sig. R-III.a.4080,41, přiv. 4 VAVÁK, František Jan, BEZSTAROSTI, František, ed. PaMátka, a DVstogná Cžest, CIsaře Iozeffa poLñIho Worán̆I. 1769. W Pjseň vwedená od Pána Frantjsska Wawáka Sauseda, a Rychtáře dédini (!) Milčic, na cýs. komornjm Panstwj Poděbradským, a spolu Měsstiana král. Města Plzně w Cžechách. [V Brně: u Jana Jiřího Gastla, po 1809]. Knihopis, K16453. KBOR, sig. R-III.a.4087,17 Zpěwy o wzkřjssenj Páně. W Praze: W knjžecj arcjbiskupské knihtiskárně, 1834. KBOR, sig. R-III.a.4062,50

Zwey schöne anmüthige Geistl. Lieder, Das Erste: Ach weh O Schmertz und Peyn, wer gibt mir Trost allein, etc. Das Andere: Jerusalem, ach wein mit mir, O Bethlehem ingleichen, etc.: Im Th: Thue auff O Himmel deine Schooß. Gedruckt zu Znaymb: bey Johann Wenc. Swoboda, [mezi 1719 a 1726?]. BCBT, č. 42842. KBOR, sig. R-III.a.4080,41, př́v. 3

Zwey schöne Ehren-Lieder Zu dem Heiligen FRANCISCO XAVERIO, Grossen Patron und Fürsprecher bey GOtt. [Česko: nakladatel není známý, mezi 1780 a 1800]. Dostupné z: http://imageserver.mzk.cz/ $m z k 03 / 001 / 181 / 256 / 328100204057 . t i t u l 2 . \quad$ KBOR, sig. R-Z.e.50, príiv. 2

Zwey schöne Geistliche Lieder. Das Erste:Von der Hochheiligsten Dreyfaltigkeit. Das Andere: Erfreut euch 
frolocket ihr Christen auff Erden, etc. Znaym: gedruckt bey Johann Wenc. Swoboda, [mezi 1719 a 1726?]. BCBT, č. 42841. KBOR, sig. R-III.a.4080,41, přív. 7

\section{Prameny:}

PIUS 1810: PIUS. Unsers heiligsten Herrn Pius aus göttlicher Vorsicht des VII. Pabst Rede. Gehalten bey der feyerlichen Heiligaprechung der Heiligen Franz Caracciolus, Benedikt vom hl. Philadelphius angela Merici, Coleta Boilet, und Hyacintha Mariscotti, unter dem feyerlichen Amt der Messe in der vatikanischen Hauptkirche zu Rom den 24. May 1807. Aus dem Lateinischen übersetzt von Emerich Rampel, Minoriten Ordens Provinzial. Brünn: [nakladatel není známý], 1810. KBOR, sig. R-E.II.g.32, př́iv. 12.

NACHRICHT: Nachricht von der feyerlichen Heiligsprechung der Seligen Franz Caraccioli, Stifter des Ordens der Mindern regulären Kleriker, Benedikt vom heil. Philadelphus, Layens der Mindern Reformirten Observanten des heil. Franciskus, Angela Merici, des dritten Ordens des heil. Franciskus, und Stifterin der Gesellschaft der heil. Ursula, Ursuliner genannt, Koleta Boilet, Reformatorin des Ordens der heil. Klara. Hyacintha Mariskotti, Professen Klosterfrau des dritten Ordens des heil. Franciskus. Gehalten mit heilig-andächtiger Pracht, von Sr. Heiligkeit unsern Herrn Pabst Pius den VII. der vatikanischen Hauptkirche, den 24ten May 1807 mit jenen Gebräuchen und kostspieligen Verzierungen, welche hier getreulich beschrieben werden. Brünn: gedruckt bey Joseph Georg Traßler, [mezi 1807 a 1810]. KBOR, sig. R- R.II.b.16 a R-E.II.g.32, př́iv. 11. Dostupné z: http://imageserver.mzk.cz/mzk03/001/205/902/ 328100215401.titul.jp2

\section{Literatura:}

BARUČÁKOVÁ 2007: BARUČÁKOVÁ, Lenka. Tiskařská produkce rodiny Svobodových. In: KRUŠINSKÝ, Rostislav (ed.). Problematika historických a vzácných knižních fondů Čech, Moravy a Slezska 2006: sborník z 15. konference Olomouc, 22.-23. listopadu 2006. Sdružení knihoven České republiky a Vědecká knihovna v Olomouci: Olomouc, 2007, s. $167-173$.

DOKOUPIL 1978: DOKOUPIL, Vladislav. Soupis brněnských tisků: staré tisky do roku 1800. Brno: Státní vědecká knihovna, 1978. Bibliografie a prameny k vývoji Moravy. Dostupné z: http://www.digitalniknihovna.cz/mzk/uuid/uuid: 42056226-12d4-45b3-95a8-abf25b4aeabd
GLOMBOVÁ 2020: GLOMBOVÁ, Hana (ed.). Do Brna široká cesta. Kramářské písně se světskou tematikou. Katalog k výstavě: Moravské zemské muzeum, 4. záři 2020 7. března 2021. Brno: Moravské zemské muzeum, 2020.

HEILANDOVÁ 2013: HEILANDOVÁ, Lucie. „Ano, kniha a noviny staly se za našich dnů téměř jako chléb potřebou vezdejší...“. In: HEILANDOVÁ, Lucie. Posledních dvě stě let v historii rajhradského kláštera. Brno: Moravská zemská knihovna, 2013, s. 60-90. Dostupné z: http:// www.digitalniknihovna.cz/mzk/uuid/uuid: fd326900-724511e9-b253-005056827e52

IVÁNEK 2017: IVÁNEK, Jakub. Poznámky k vymezení pojmu kramářská píseň. Listy filologické 140, 2017, č. 1-2, s. 200-229.

PAVELKOVÁ 2018: PAVELKOVÁ, Jindra. Das Interesse des Klosters Raigern Rajhrad) an der Außenwelt aus der Perspektive des Fascis diversarum. In: ČERNUŠÁK, Tomáš - KOLLERMANN, Karl - RABL, Irene (edd.). Monastica historia. Band 3. Kommunikation zwischen Kloster und Welt in Spätmittelalter und Früher Neuzeit. St. Pölten - Praha: Diözesanarchiv St. Pölten - Historický ústav AV ČR, 2018, s. 81-98.

RAK 2010: RAK, Jiří. Zachovej nám, Hospodine. Acta universitatis Carolinae - Historia Universitatis Carolinae Pragensis 2010, sv. I., č. 1, s. 257-265.

VOBR 2005: VOBR, Jaroslav. České tisky Moravské zemské knihovny v Brně a jihomoravských klášternich knihoven z let 1501-1800. Brno: Moravská zemská knihovna v Brně, 2005. Dostupné z: http://www.digitalniknihovna.cz/mzk/ unid/unid:6a0335ad-954f-409e-b834-72ce8235c9ec

\section{Elektronické zdroje:}

Kramářské písně. In: Encyklopedieknihy.cz [online]. Knihovna AV ČR, v. v. i. [Cit. 1. 5. 2021]. Dostupné z: https://www.encyklopedieknihy.cz/

\section{| Jindra Pavelková}

Moravská zemská knihovna

Kounicova 65a

60187 Brno 